\title{
REVIEW
}

Open Access

\section{Review on the extraction of bioactive compounds and characterization of fruit industry by-products}

Abhipriya Patra, S. Abdullah and Rama Chandra Pradhan *(i)

\begin{abstract}
The by-products produced from fruit processing industries could be a potential hazard to environmental pollution. However, these by-products contain several biologically active molecules (essential fatty acid, phenolic compounds, flavonoids, coloring pigments, pectin, proteins, dietary fibers, and vitamins), which can be utilized for various applications in the food, pharmaceutical, cosmetic and textile industries. Nevertheless, during extraction, these bioactive compounds' recovery must be maximized using proper extraction technologies, keeping both economy and environment under consideration. In addition, the characteristics of the extract obtained from those by-products depend mainly on the parameters considered during the extraction process. In this review, an overview of different technologies used to extract bioactive compounds from fruit industry by-products such as seeds and peels has been briefly discussed, along with their mechanisms, process, advantages, disadvantages, and process parameters. In addition, the characteristics of the extracted bioactive compounds have also been briefly discussed in this review.
\end{abstract}

Keywords: Fruit by-products, Extraction technologies, Biowaste valorisation, Characterization, Bioactive compounds

*Correspondence: pradhanrc@nitrkl.ac.in

Department of Food Process Engineering, National Institute

of Technology, Rourkela, Odisha 769008, India

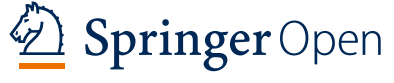

(0) The Author(s) 2022. Open Access This article is licensed under a Creative Commons Attribution 4.0 International License, which permits use, sharing, adaptation, distribution and reproduction in any medium or format, as long as you give appropriate credit to the original author(s) and the source, provide a link to the Creative Commons licence, and indicate if changes were made. The images or other third party material in this article are included in the article's Creative Commons licence, unless indicated otherwise in a credit line to the material. If material is not included in the article's Creative Commons licence and your intended use is not permitted by statutory regulation or exceeds the permitted use, you will need to obtain permission directly from the copyright holder. To view a copy of this licence, visit http://creativecommons.org/licenses/by/4.0/. 


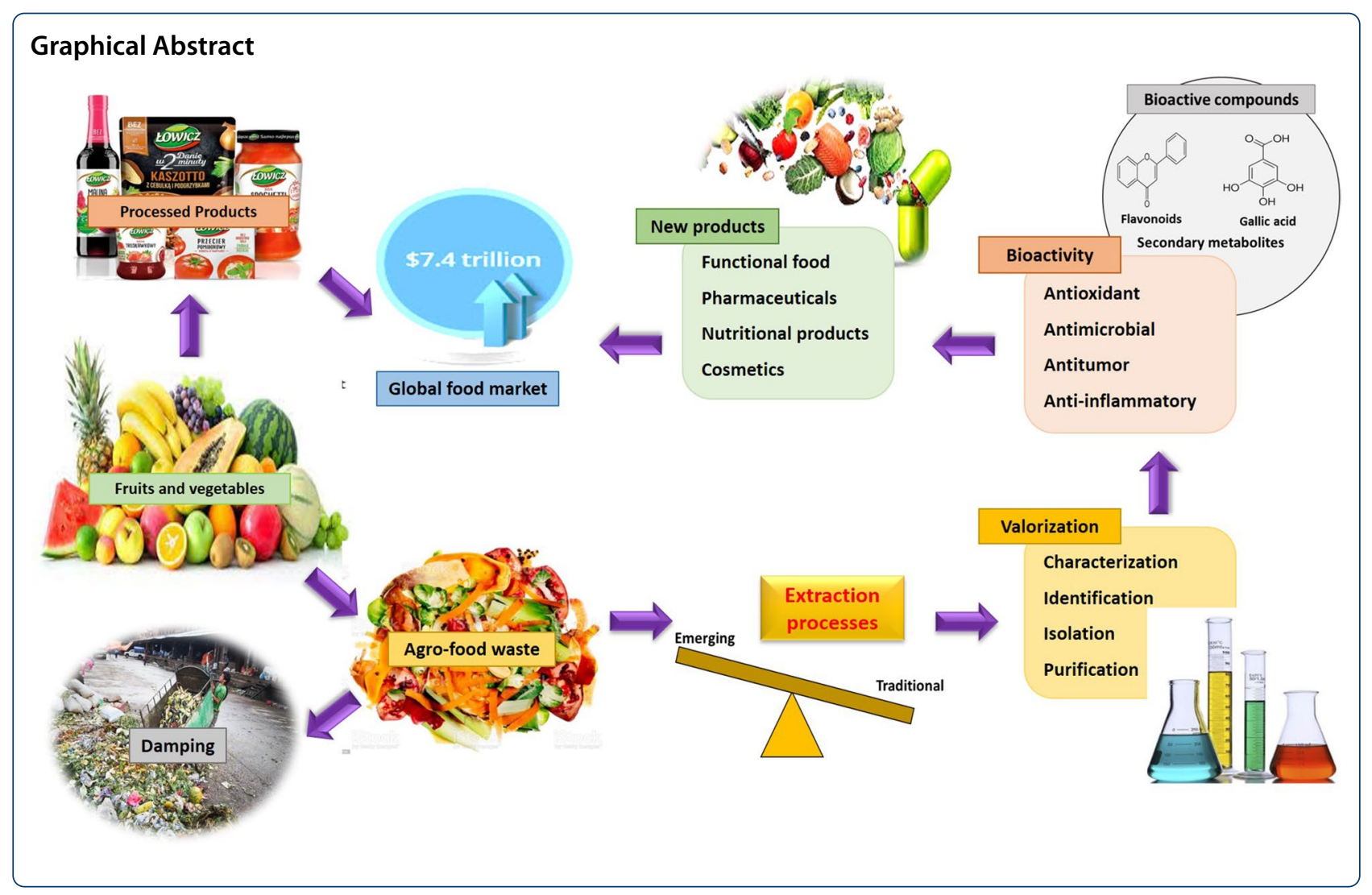

\section{Statement of novelty}

The by-products management of fruit and vegetable industries are becoming a universal concern. The problems can be lessened by applying the extraction conception which means the recovery of bioactive compounds, vitamins, fatty acids, minerals and polysaccharides from the bio-residues, such as seeds and peels. Several studies in the literature have reviewed the different extraction technologies for the valorization of waste. In addition, the technologies are compared with their acceptance of the industrial level. However, the review has also explored the different characterization processes of extracted bioactive compounds. Moreover, integration between two or more extraction technologies for the recovery of bioactive compounds have been enlightened in this review. Overall, this study describes the valorization of waste produced from industries by extracting bioactive compounds with help of different traditional and novel extraction technologies.

\section{Introduction}

Fruits are the potential source of various nutrients, such as macronutrients (carbohydrate, lipids, protein) and micronutrients (vitamins, minerals, bioactive compounds). Hence, these are converted into different processed products, such as juice, jam, jelly, beer, wine, sauces, pickles, and several other products. The global production of fruits is about 503.3 million metric tons; however, only 1.4 million metric tons are commercially processed into different products. During processing, the industries produce and discard at least $25-30 \%$ of each fruit as waste products or by-products (Mahato et al. 2019). The significant by-products from fruit processing industries include peel/skin, seeds, leaves, tubers, roots, and pomace. Discarding these by-products harms the environment and generates an economic burden to the concerned industries (Altemimi et al. 2017a; Chemat et al. 2012; Kapoor et al. 2020).

On the other hand, these by-products are an excellent source of bioactive compounds, such as phenolic compounds (phenolic acid, carotenoids, flavonoids), bioactive proteins (peptide isolate, amino acids), fatty acids, fibres, and so on. For instance, the seeds of fruits are a good source of essential oils, phytochemicals, and phytosterols. Similarly, the peels contain pectin, valuable fibers, and minerals (Marić et al. 2018; Mena-García et al. 2019). These bioactive compounds can be extracted from the by-products using different technologies and can be utilized to develop various valorized products, including functional foods or dietary supplements. In addition, in 
this way, the disposal of waste to the environment can be minimized.

The extraction technologies are categorized according to their extraction efficiency, cost-effectivity, and sustainability. Several extraction processes are followed for the recovery of bioactive compounds from the fruit industry by-products. These compounds can be separated, identified, and characterized to be utilized by different food, pharmaceutical, cosmetic or textile industries (Altemimi et al. 2017a; Marić et al. 2018). The bioactive compounds cause a lower risk of cancer, cataract, Alzheimer's, Parkinson's disease, ageing disorder, and heart-related diseases. Due to their high antioxidant activity and antimicrobial activity, these compounds perform defensive action toward chronic diseases, preventing the production of cancerous chemicals and balancing the immunosystem. These compounds are beneficial by being used as an additive in functional foods or consumed as a dietary supplement. Besides nutraceutical properties, natural antioxidants and colour compounds can be a better replacement for synthetic antioxidants, which could be used in different pharmaceutical and processing industries (Altemimi et al. 2017a; Azmir et al. 2013; Sasidharan et al. 2011). The processes starting from extraction to separation, isolation, identification, and characterization of fruit byproducts were summarized in the flow chart shown in Fig. 1. Thus, the extraction and valorization of bioactive compounds from fruit industry by-products improve societal health by providing nutritious food, mitigating the environmental problem, and reducing the waste disposal burden. It, therefore, helps the industries from an environmental and economic point of view (De Ancos et al. 2015; Kowalska et al. 2017; Trigo et al. 2020).

This review aims to provide an overview of the fruit industry by-products, a rich source of bioactive compounds. In addition, conventional (soxhlet, maceration, and hydrodistillation) and emerging (supercritical fluid, subcritical fluid, microwave-assisted, ultrasonicassisted, enzyme-assisted, and pulsed electric fieldassisted) techniques, along with separation, isolation, and

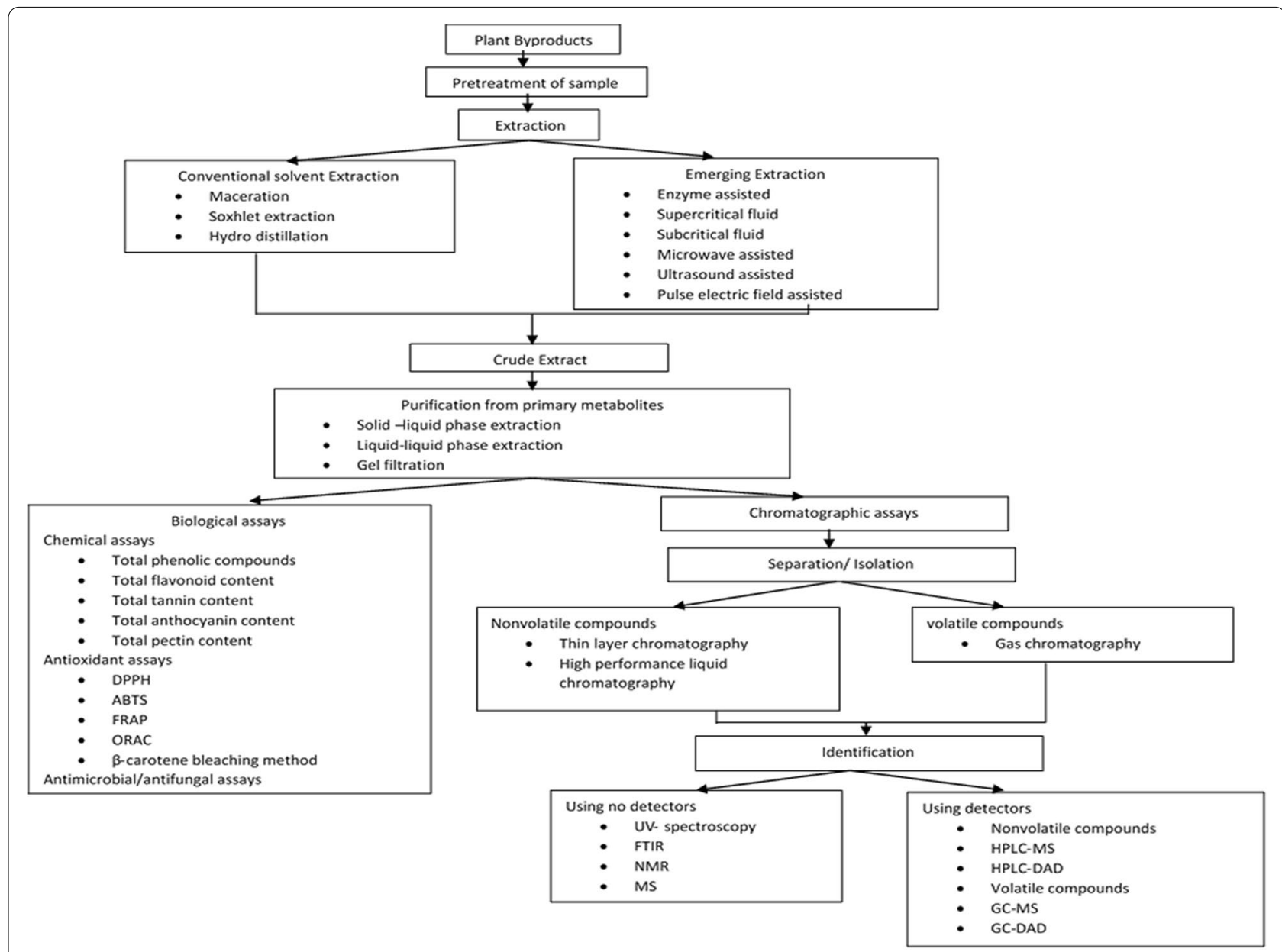

Fig. 1 Flow chart showing the extraction and characterization of bioactive compounds from fruit by-products 
identification by different analytical methods and quantification using various chromatographic and spectrophotometric methods. Furthermore, this review enlights on the mechanisms, advantages, and disadvantages of the above extraction techniques.

\section{By-products from fruit industries}

Major industrial by-products from fruits and their nutritional significance are discussed here. Guava seeds contain around $16 \%$ oil, making them good sources of edible oil. These also contain about $61.4 \%$ crude fiber and $7.6 \%$ protein. However, until recently, guava seed oil has only been exploited to prepare mono-acylglycerol and diacylglycerol (Raihana et al. 2015). Similarly, pomegranate seeds are a good source of high-quality oil (12-24\%), polyunsaturated fatty acids (especially the conjugated punicic acid), protein (10-20\%), and insoluble fibers (in which around $30-50 \%$ is cellulose and hemicellulose) (Aruna et al. 2016). Likewise, the apple seeds are rich in oil (17-23\%) containing unsaturated fatty acids in high concentration and phenolic compounds, such as phloridzin and quercetin-3-galactoside fibers (20\%) (Walia et al. 2014).

The by-products produced after the processing of avocados are about $21 \%$ of the weight of its fruit. These by-products are rich in carbohydrates (43-85\%), lipids (2-4\%), proteins (3-9\%), and minerals (2-4\%). In addition, the avocado peels contain a high amount of carbohydrates $(44-84 \%)$, lipids (2-6\%), protein (3-8\%), and minerals (2-6\%) (Bressani et al. 2009). On the other hand, the avocado seed kernels have $3-4 \%$ lipids, $3 \%$ proteins, $20-23 \%$ insoluble fibre, and $63-65 \%$ carbohydrates (Araújo et al. 2020). Similarly, mango's by-products constitute about $12-15 \%$ peel and 15-20\% seed kernel which contains fatty acid, triacylglycerols, gallotanins, xanthone, and flavonoids (Jahurul et al. 2015). Mango peels are good sources of antioxidants, protein, pectin, which has different food and pharmaceutical applications (de Lourdes García-Magaña et al. 2013).

The papaya fruit contains $15-20 \%$ seed which is rich in oils (30\%) with palmitic, stearic, oleic, linoleic acids, carpaine, glucotropacolin, benzyl isothiocyanate (BITC), caricin (sinigrin), and anzymemyosin as primary fatty acids (Vij and Prashar 2015). Pineapple peel with 30-42\% fruit weight contains a high amount of cellulose, hemicelluloses, lignin, and pectin. Rambutan fruit peels contain a high amount of pectin (Maran and Priya 2014). Pear peel contains colour pigments with commercial applications. By-products of peach contain bioactive compounds, such as vitamin $C$ and polyphenols, which show antioxidant activities (Redondo et al. 2017). Dragon fruit peels contain beta-carotene, lycopene, vitamin E, essential fatty acid and is also a good pectin source (Thirugnanasambandham et al. 2014).

\section{Extraction of bioactive compounds from fruit by-products}

Different extraction technologies are utilized to extract beneficial compounds, especially bio-actives, present in the innermost portion of the cell of fruit by-products. A schematic diagram of available extraction technologies along with their mechanism of action is given in Fig. 2 . The selection of technology for the extraction process is based on the required degree of purity of the extract, physical and chemical properties of the compound of interest, the location of the compound to be extracted (i.e., either it is free or it is bounded inside the cell of the by-products), cost-effectiveness and value of the extracted product. Before extraction processes, there are several unit operations to be done for better yield. Washing, cutting, size reduction, and drying are examples of various unit operations (Gong et al. 2020).

The standard conventional extraction techniques take a lot of time, energy, and solvent during processing and have some drawbacks. Due to this, emerging technologies are popularly used these days in pharmaceuticals, food, and medicinal industries. They require fewer solvents, less extraction time, and have more extraction efficiency than conventional technologies (Belwal et al. 2020). These technologies are selected based on their advantages, disadvantages, operation principles, and equipment types available for extraction. The operation parameters, advantages, and disadvantages of different extraction technologies are described in Table 1.

Mainly the extraction process has the following objectives: (a) to extract the targeted bioactive compounds from complex plant samples, (b) to increase the selectivity of analytical methods, (c) to increase the sensitivity of bioassay by increasing the concentration of targeted compounds, (d) to convert the bioactive compounds into a more suitable form for detection and separation, and (e) to provide a reproducible and robust method that is independent of variations in the sample matrix (Azmir et al. 2013). However, the basic mechanisms of all the solvent extraction processes are: (1) the solvent penetrates the solid matrix; (2) the compound of interest dissolves in the solvents; (3) the compounds diffused out of the solid matrix; (4) the extracted compounds are collected (Smith 2003).

The factors affecting the different extraction process is illustrated in Table 1. Besides those, the primary factors influencing extraction efficiency are the type of solvents used, extraction time, the particle size of the sample, temperature of extraction, and solid/solvent ratio (Garavand et al. 2019). The particle size must be small to penetrate 


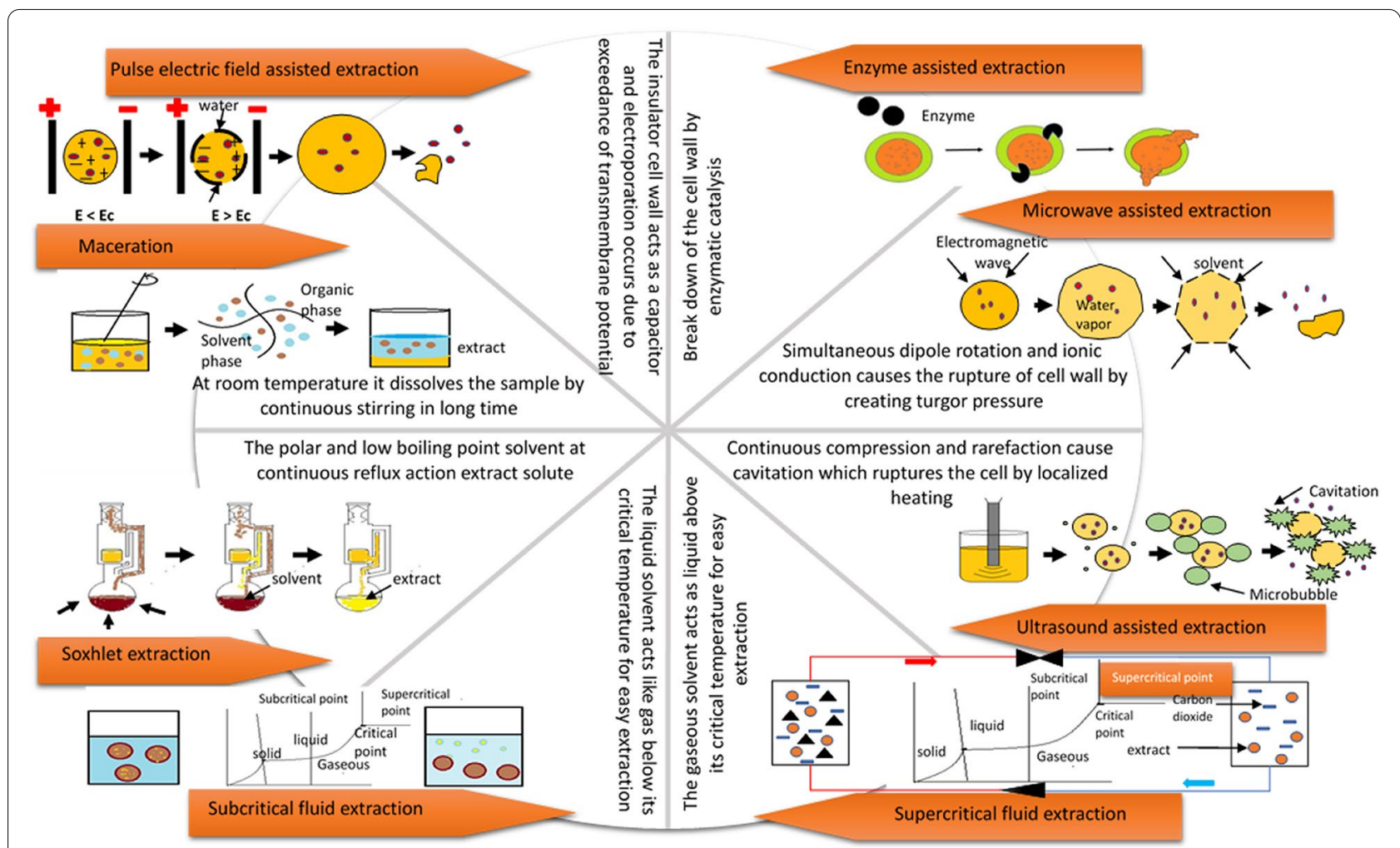

Fig. 2 Mechanism of conventional and emerging extraction technologies with schematic diagrams

the solvent inside the sample, and the temperature should be high for a higher yield. But too much high temperature can cause the loss of volatile compounds during the extraction process. Too much duration cannot affect the extraction, since the extraction process attains an equilibrium state after a specific time. The ratio between solid and solvent should be moderate; a too-high ratio might take more time for extraction (Zwingelstein et al. 2020).

Industrial scaling up of the extraction requires extensive consideration of both economy and productivity, while the lab-scale extractions require only a small amount of raw materials and solvent. Several factors are considered during the large-scale extraction process, such as instrumentation, type of process (batch or continuous), kinetics, economics, and energy consumption (Belwal et al. 2020; Chemat et al. 2012). There have been many investigations about scaling up the extraction processes. About $60 \%$ of industrial applications are done with SFE, while $15 \%$ and $14 \%$ of extraction are carried out with ultrasound and microwave, respectively (Belwal et al. 2020; Chemat et al. 2019). In the case of the UAE, both probe and bath systems are used on pilot / industrial scales, and microwave reactors are usually preferred in industrial proposed extraction. Meanwhile, UAE is the primarily used extraction process for industrial-based juice production. However, in the case of PEF-assisted extraction process, there are still challenges for the industrial scaling up of the process.

\section{Bioactive compounds present in fruit by-products}

The bioactivity of fruits and vegetables is defined as the capacity to counteract the adverse effects of oxidative stress on human health, such as several human diseases, such as diabetes, cancer, cardiovascular diseases, osteoporosis, etc. The bioactive compounds are a secondary metabolite of the plant and can be classified into essential and non-essential nutrients. The phenolic compounds, dietary fibers, and fatty acids are non-essential, while the vitamins and minerals are essential nutrients (Guil-Guerrero et al. 2016; Padayachee et al. 2017).

The byproducts of fruits contain phytochemicals comprising phenolic compounds, vitamins, minerals, dietary fiber, and other bioactive compounds. The polyphenolic compounds present inside the fruit cause immunity towards the development of human health. The phenolic compounds are the secondary metabolite of the fruits, which can act against the free radicals and oxidative stresses, and hence they are called antioxidants (Singh et al. 2017; Trigo et al. 2020). These are structurally complex compounds containing high molecular 


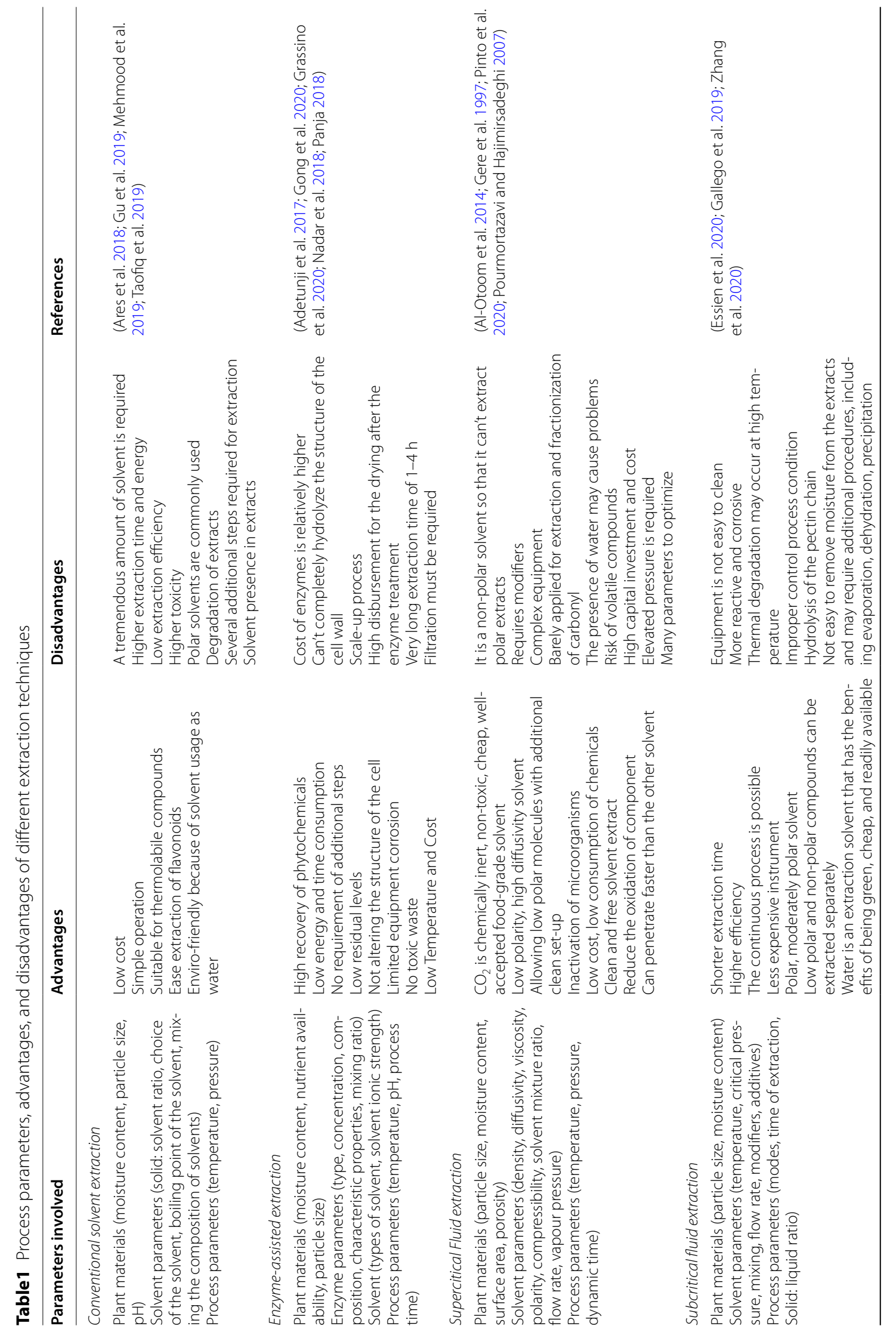




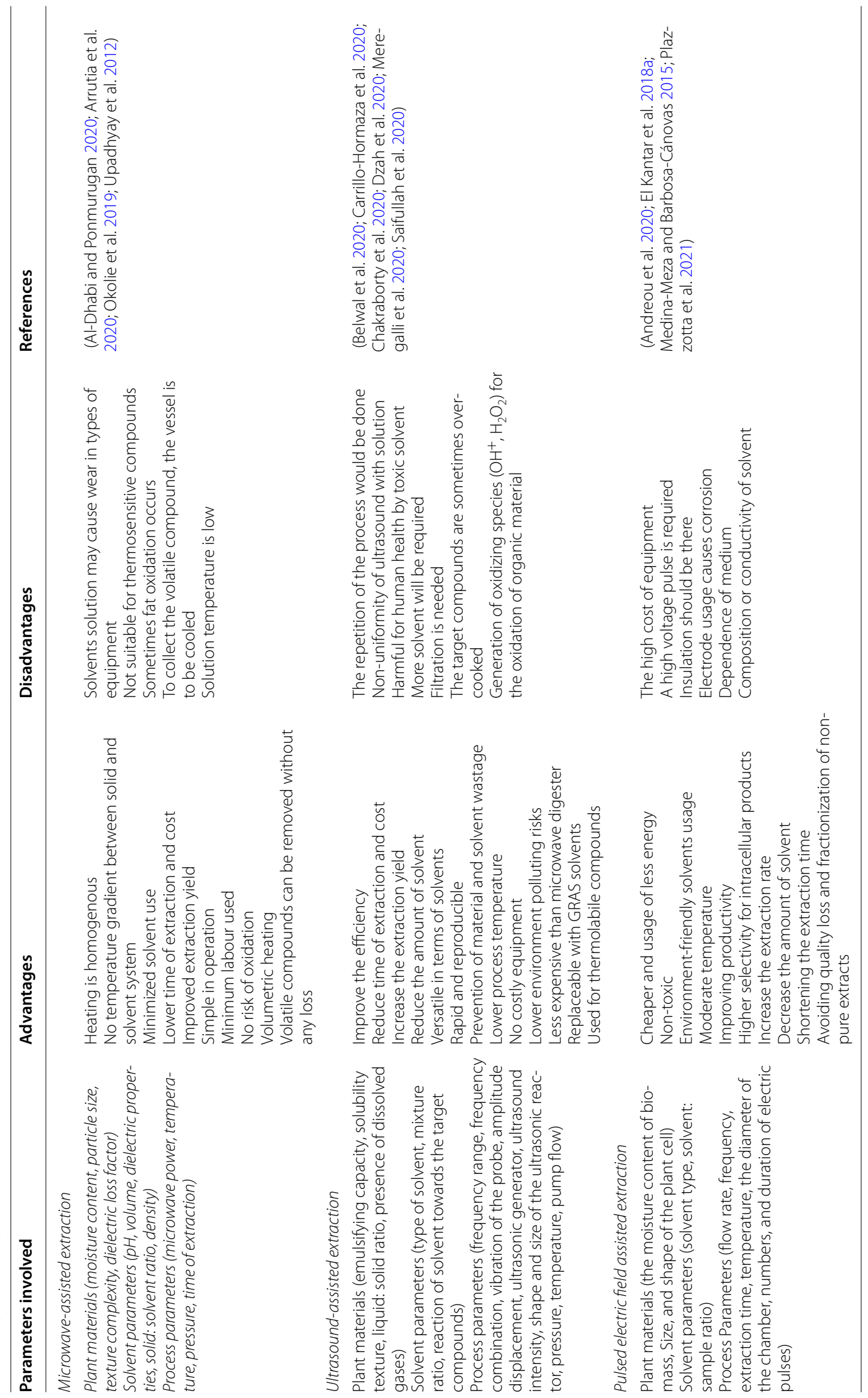


weight phenols which bear at least one or more hydroxyl groups in the aromatic ring. Commonly, the phenolic compounds are in the form of flavonoids, phenolic acids, and tannin (Babbar and Oberoi 2014). The phenolic acid is formed by one phenolic ring with a carboxylic acid. Some examples of phenolic acids are hydroxybenzoic acid, hydroxycinnamic acid, gallic acid, ferulic acid, and cinnamic acid. These compounds exhibit higher antioxidant and antimicrobial activity, which mainly depend on the position of the hydroxyl and carboxyl groups and the double bonds present in the ring (Akhtar et al. 2015; Sanchez-Maldonado 2014). Besides phenolic acids, flavonoids also have biological properties, such as antioxidative, antimicrobial, anticancerous, and cardioprotective. Flavonoids are heterocyclic aromatic rings comprising flavonol, flavanone, flavones groups, where catechin, hesperetin, and proanthocyanidin are a few examples (Yalcin and Çapar 2017). Tannins are water-soluble phenolic compounds divided into galotannins, ellagitannins, condensed tannins, and complex tannins. These compounds also exhibit antioxidant activity due to the presence of the phenol hydroxyl groups, which are capable of reducing the free radicals and antimicrobial activity by inactivating the enzymes as well as precipitating the proteins (Akhtar et al. 2015; Guil-Guerrero et al. 2016).

Anthocyanins are water-soluble plant pigments of red, purple, and blue colour, derived from the peel of fruits, such as pear, watermelon, and apple. Similarly, carotenoids are another water-insoluble/ Lipid soluble plant antioxidants that are the precursors of vitamin A. Carotene (lycopene, $\beta$-carotene, $\alpha$-carotene), xanthophyll (lutein) are some examples of carotenoids present in seeds and peels of the fruit. The arrangement of conjugated double bonds is responsible for the antioxidant activity of the carotenoids (De Ancos et al. 2015). Vitamins present in fruits and vegetables are responsible for preventing lipid oxidation, decreasing DNA damage, and maintaining immune function. Ascorbic acid and tocopherols are precursors of vitamin $\mathrm{C}$ and vitamin $\mathrm{E}$, respectively. $\alpha, \beta, \gamma, \delta$ tocopherols are four analogues that are responsible for hypolipidemic, antiatherogenic, antihypertensive, allergic dermatitis suppressive, neuroprotective, and anti-inflammatory activities (Golkar and Moattar 2019). The polysaccharides present in the cells of fruit by-products are responsible for the antihyperlipidemic, prebiotic, antitumor activities, and jellification and emulsification efficiencies. The polysaccharides are classified into water-soluble (pectin) and water-insoluble (cellulose, lignin) groups. Pectin is a heterogeneous type of acidic polysaccharides present in the cell lamella of fruits. Besides these, the oils extracted from the seed or peel powder, described in Table 2, have antioxidant, anticancerous, and antidiabetic properties because of the presence of fatty acids, such as polyunsaturated (linoleic acid, linolenic acid), and monounsaturated (oleic acid) (Golkar and Moattar 2019; Minh et al. 2019; Peso-Echarri et al. 2015; Yalcin and Çapar 2017).

\section{Characterization of bioactive compounds}

After extraction, the bioactive compounds are separated, purified, and identified to determine the presence of specific compounds in specific quantities. These compounds are also categorized by functional activities, which are determined by different bioactivity assays. Many analytical methods are used for the separation, purification, and identification of bioactive compounds, but the screening of those methods are done according to the simplicity, specificity, and speed (Altemimi et al. 2017a; Sasidharan et al. 2011). Column chromatography techniques are used to separate and isolate the desirable compounds from the mixture of extracts. The bioactive compounds are separated and purified based on their adsorption properties, molecular size, ionic strength, boiling points, and so on (Zhang et al. 2018). Adsorption column chromatography is the technology in which the target molecules are separated based on affinities towards the adsorbent surfaces, such as silica gel, aluminium oxide, polyamides, and silver nitrates. On the other hand, the partition chromatography and counter-current chromatography are based on the liquid-liquid extraction in which one liquid phase is stationary, and another liquid phase is in the mobile phase. Moreover, in the case of membrane filtration and gel chromatography, the bioactive compounds are separated by molecular size. The smaller molecule can pass through while the large molecular particles are retained. In the case of gel chromatography, the bioactive compounds are purified according to their retention time. Meanwhile, the ion-exchange chromatography separates the bioactive compounds based on net surface charge. In this, the molecules can be caught or released by ion-exchange resin by changing the ionic strength of the mobile phase. However, in the case of distillation, the thermosensitive or high molecular weight bioactive compounds can be separated (Altemimi et al. 2017b; Mahato et al. 2019; Raje et al. 2019). For identification and quantification, the bioactive compounds are determined using several spectroscopic techniques. There are various bioactivity assays for measuring its functional activities, such as antioxidant activity, antimicrobial activity, and so on. Before all the above procedures, the extracts are first refined from interfering common metabolites using different pretreatment procedures to make the preconcentration of secondary metabolites. Moreover, the quantification of these compounds is also demonstrated by many chemical assays (Bailey 2015; Roberts and Caserio 1977). 


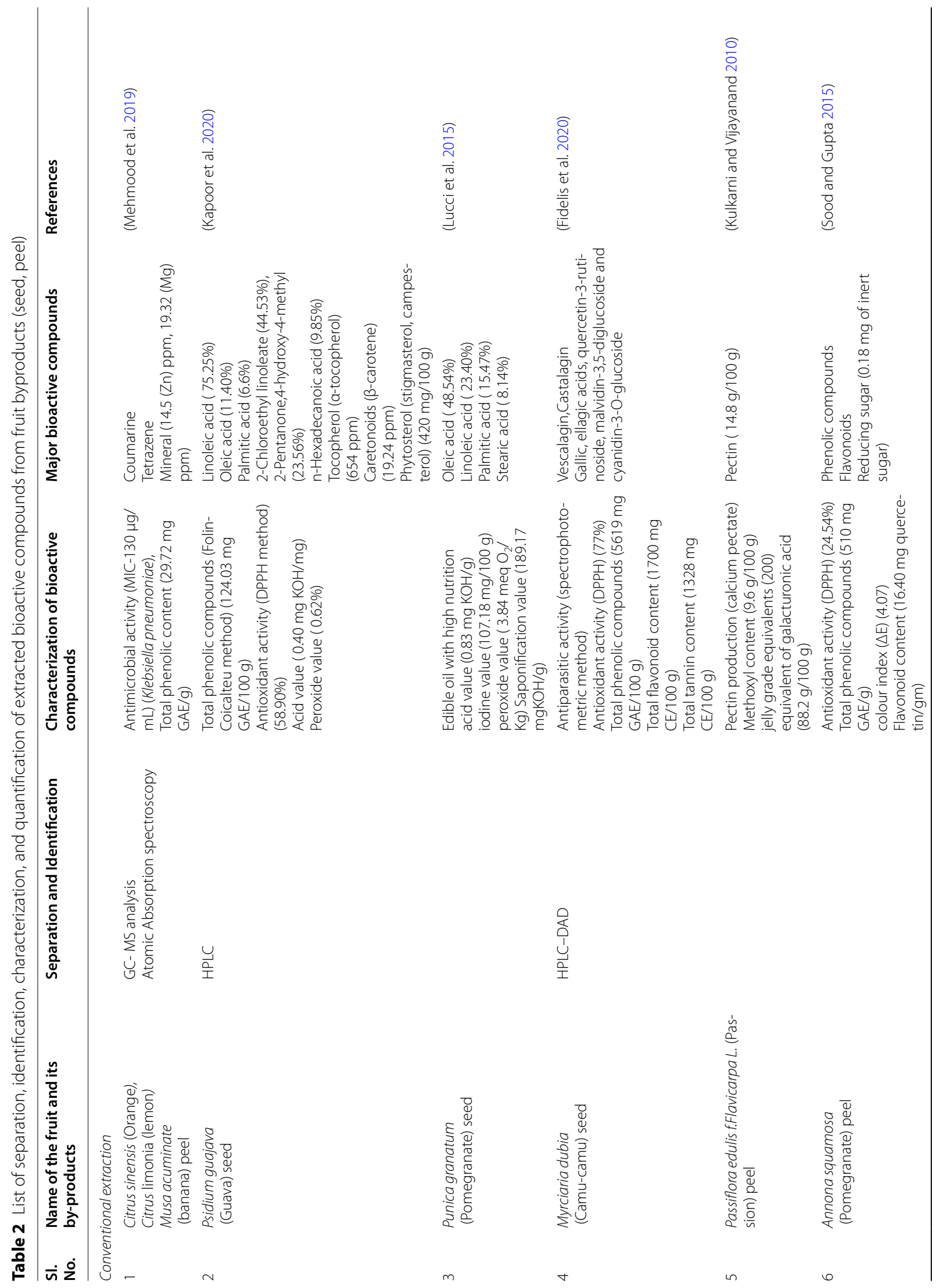




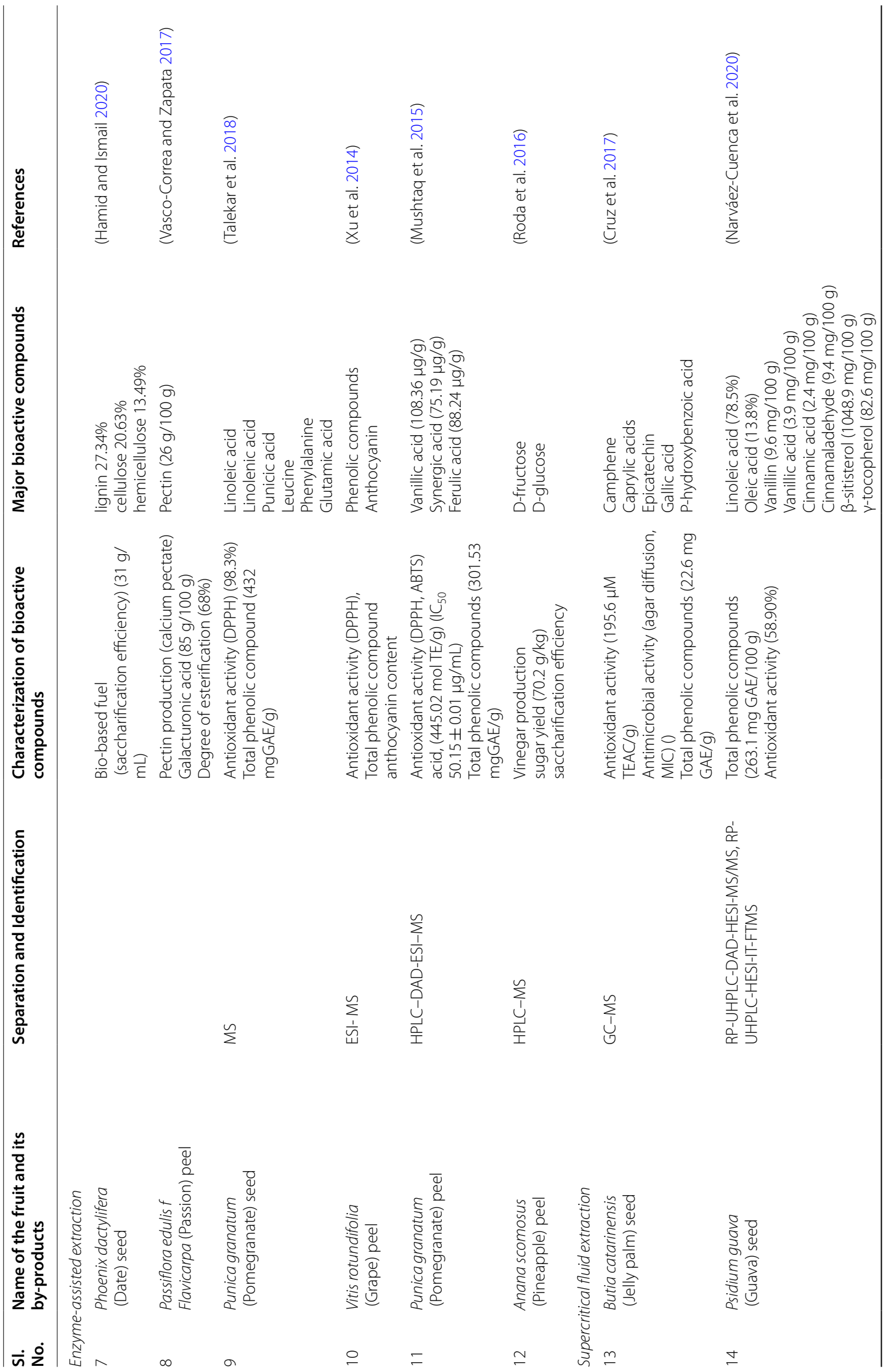




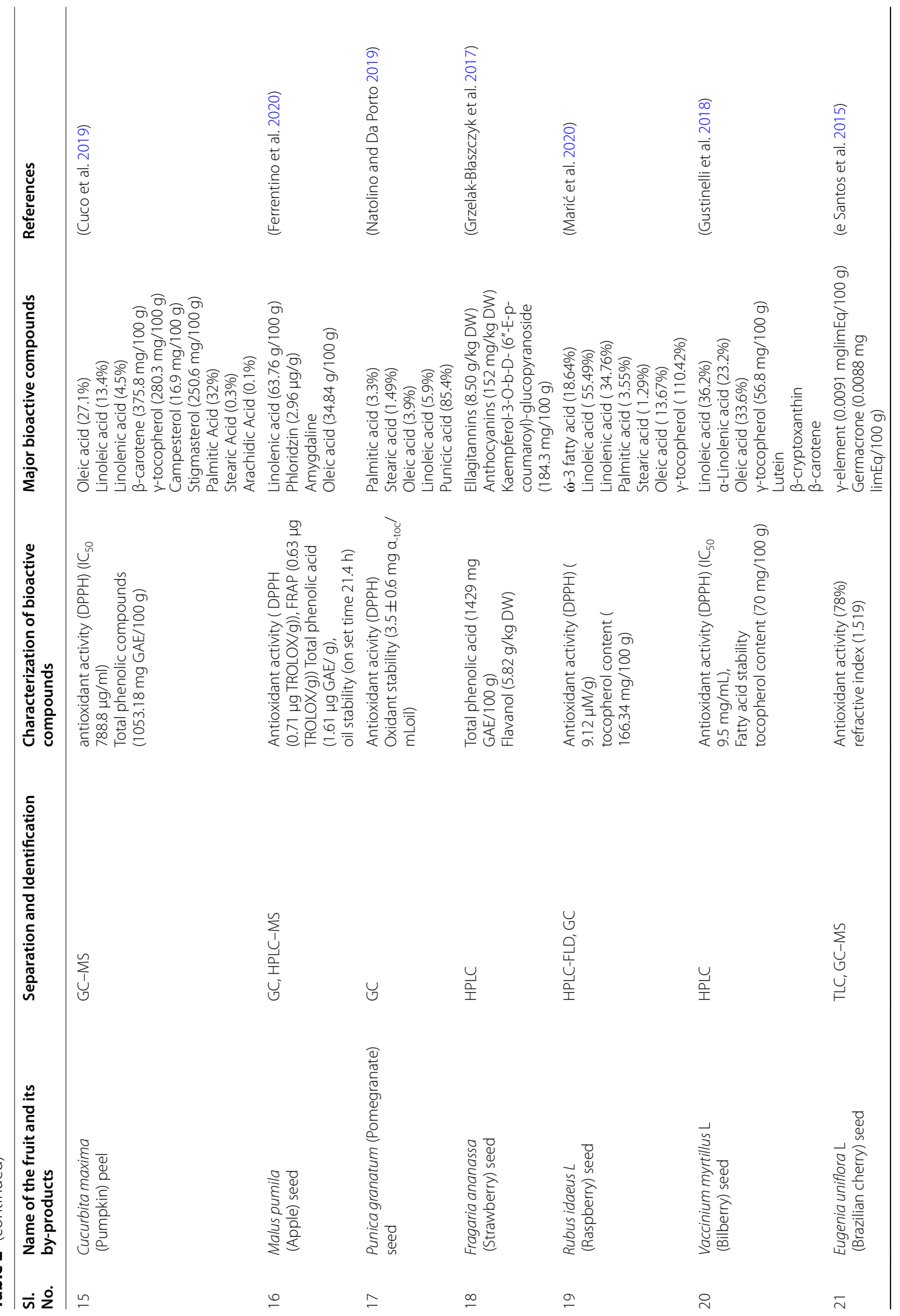




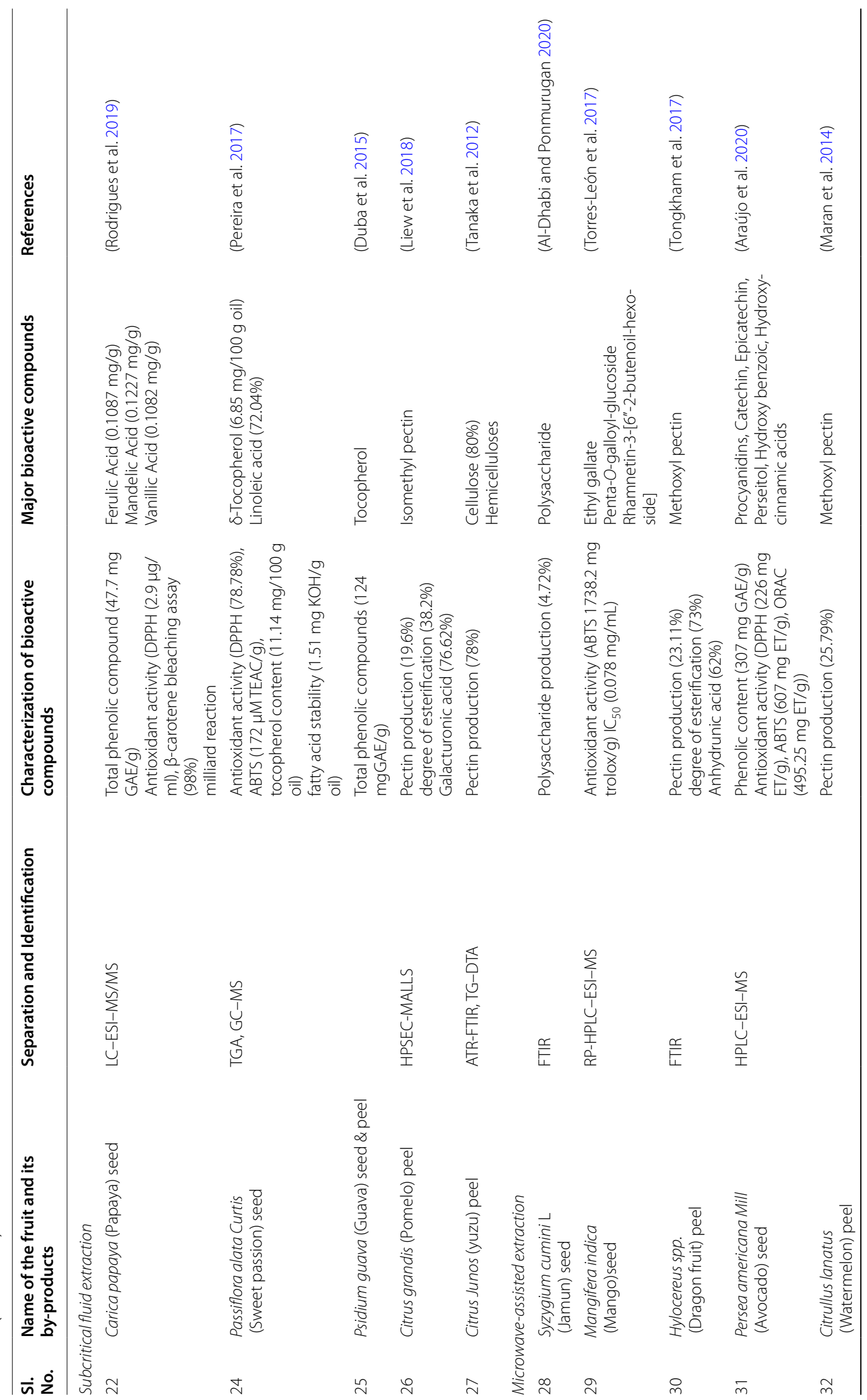


Patra et al. Bioresources and Bioprocessing ～(2022) 9:14

Page 13 of 25

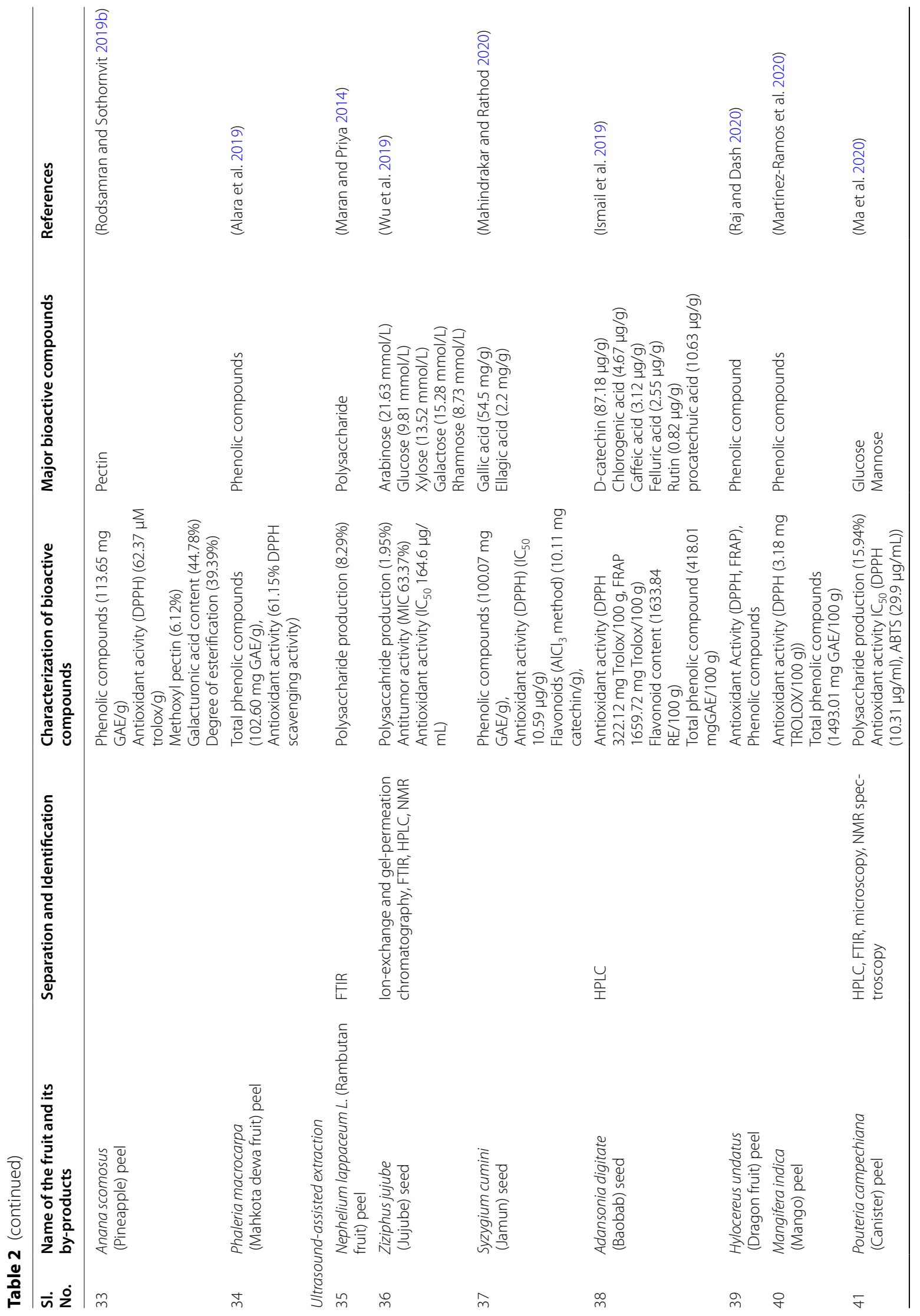




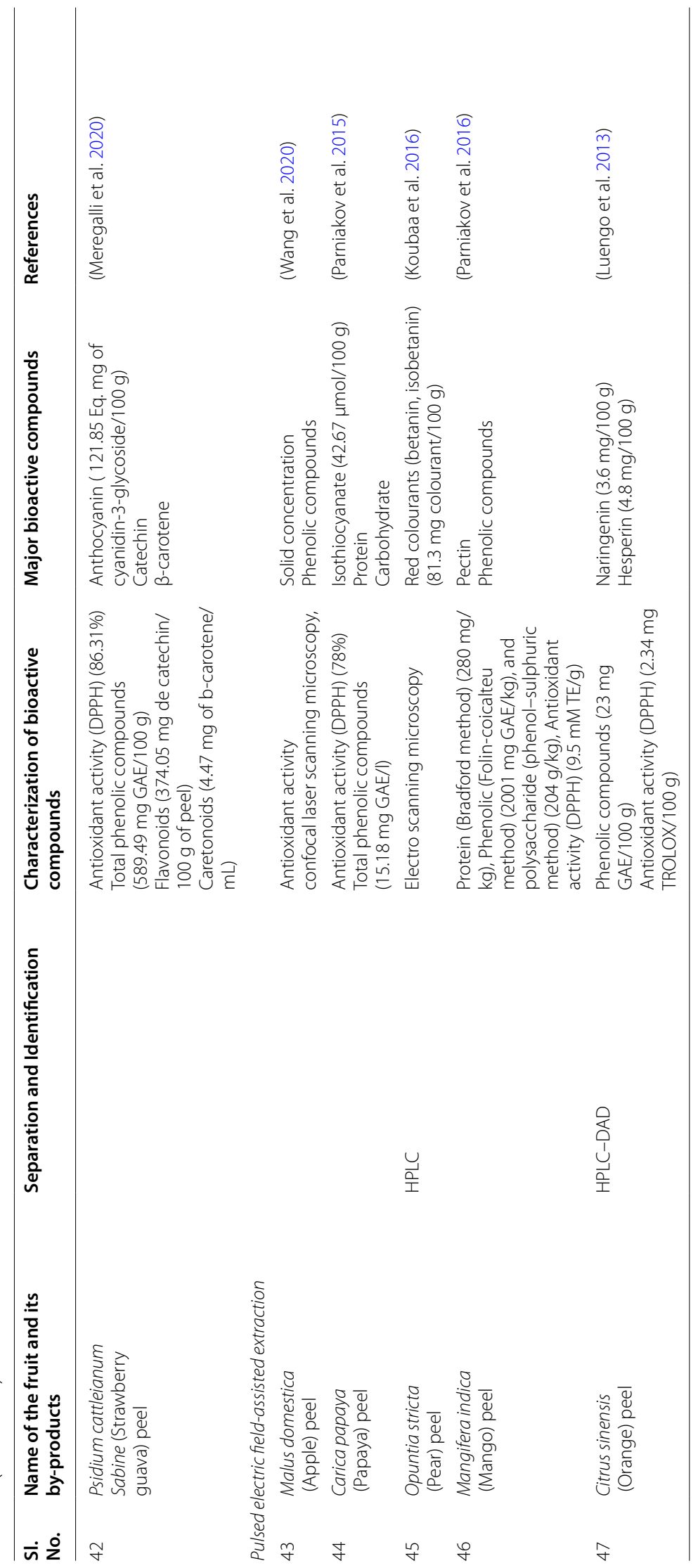


The chemical assays are demonstrated for the determination of phenolic compounds, tannins, vitamins flavonoids, pectin, and fatty acid content in various analyses in which the quantities of those compounds are calculated using the equivalent of standards, such as gallic acid, tannic acid, catechin, galacturonic acid, oleic acid and so on. After that, there are several bioactivity assays, such as different radical scavenging (DPPH, ABTS), oxygen reducing power (ORAC), carotene bleaching, iron-chelating (FRAP) assays, microbial inhibition capacity for determination of antioxidant activity, antimicrobial activity, respectively (Ivanović et al. 2020; Trigo et al. 2020).

The separation and isolation of bioactive compounds are determined by chromatographic methods, distinguished by their polarity. Gas-liquid chromatography (Gas chromatography) is used, while the extract contains some slight volatile compounds and liquid-solid chromatography [thin-layer chromatography (TLC), highperformance liquid chromatography (HPLC] are used, while the mixture contains high molecular weight molecules (Altemimi et al. 2017a). The presence of polar compounds in those compounds is separated to the other side of the column, leaving the mixture.

Finally, after the isolation of bioactive compounds, various spectroscopic methods are used for identification, composition, and bonding inside the molecules. The basic principle of these methods is the absorption of electromagnetic radiation by the molecules, which gives a spectrum. The spectra are meant for identification as every spectrum is specified for each type of bonding in the molecule. UV-visible, Fourier transform Infrared spectroscopy (FTIR), Nuclear Magnetic Resonance (NMR), and mass spectroscopy (MS) are some examples of those methods (Ivanović et al. 2020; Sasidharan et al. 2011).

However, the combination of sensitive and rapid analytical techniques with spectroscopic methods is popularly used for rapid identification and quality control of complex extract. HPLC/GC is widely used for isolation, identification for quantitative and qualitative analysis of extract; it is coupled with MS, FTIR, NMR, and so on (Trigo et al. 2020). To increase the speed of analysis, higher separation efficiency, and sensitivity, ultrahighpressure liquid chromatography is achieved. In addition, for detection of chromophores (polyphenols, flavonoids, alkaloids, quinones) and non-chromophores (terpenes, saponins), the detectors, such as UV-diode ray (DAD), Evaporative Light Scattering Detector (ELSD), Electron Capture Detector (ECD), MS, NMR and so on. The selection of detectors depends on nature, properties of bioactive compounds, their sensitivity, and the proposed information to be needed (structure, quantification) (Altemimi et al. 2017a; Ivanović et al. 2020; Sasidharan et al. 2011). The separation, identification, characterization of bioactive compounds from fruit byproducts (seed, peel) using several extraction methods are described in Table 2.

\section{Effect of extraction technologies on bioactive compounds}

\section{Conventional extraction (CE)}

Different CE processes used to separate bioactive compounds from plant materials are maceration, soxhlet extraction, percolation, infusion, digestion, decoction, and heat reflux extraction (Mehmood et al. 2019). These extraction processes are also called solvent extraction processes, because they require more amounts of mild or more polar solvents for extracting directly from biomass. Different types of solvents used in these processes are ethanol, methanol, hexane, n-butane, petroleum ether, and water. Besides the above conventional extraction processes, some processes where water is used as solvent are hydro distillation, steam distillation, steam water distillation, and steam diffusion. Different processes are distinguished by the amount of solvent used, types of equipment used, and compounds extracted. Soxhlet extraction is more suitable than maceration due to less solvent used, but it can degrade some amount of natural compounds due to high temperature. Hydrodistillation is used to separate volatile organic compounds, since it requires only less time for extraction. Maceration is used to remove thermolabile compounds, since it requires only normal room temperature (Memarzadeh et al. 2020; Taofiq et al. 2019).

The main factors that affect the CE processes are the type of solvent and its characteristics (Gu et al. 2019; Zengin et al. 2020). Lower polar solvents (petroleum ether, chloroform, etc.) extract lipophilic compounds and certain pigments, such as carotenoids and chlorophyll. However, high polar solvents are generally used to extract bioactive compounds (Ares et al. 2018). Moreover, they are best for extracting flavonoids and anthocyanins due to their acidified condition (Okolie et al. 2019).

Fruits such as orange, lemon, and banana are highly nutritious and provide health benefits to humans. The peels of these fruits are composed of phenolic compounds and minerals which show antimicrobial properties and are beneficial for therapeutic purposes (Parashar et al. 2014). Saleem and Saeed (2020) conducted a study on extracting bioactive compounds from fruit peels using CE technologies with methanol, ethyl acetate, ethanol, and distilled water. They reported that the extracted compounds exhibited antimicrobial properties. The microbial inhibition concentration (MIC) was recorded as $130 \mu \mathrm{g} / \mathrm{ml}$ during testing the microorganism (Klebsiella 
pneumoniae). At the same time, the water was considered a solvent in the extraction of yellow lemon peels. For the extraction, the solvent used were methanol, ethyl acetate, ethanol, and distilled water.

Similarly, another study reveals that the guava seed, a by-product of the guava juice industry, has an oil content of $16 \%$. In addition, the yield of oil extracted was higher (13.63\%) during soxhlet extraction than supercritical fluid extraction. Furthermore, the oil was extracted using $\mathrm{n}$-hexane for $60{ }^{\circ} \mathrm{C}$ up time $4 \mathrm{~h}$ in a soxhlet extractor (Kapoor et al. 2020).

Lucci et al. (2015) extracted oil from pomegranate seed from solvent extraction, taking ethanol as a solvent containing bioactive lipid compounds, such as punicic acid, glycolipid-linoleic, a-linoleic acids phospholipids. They also found that the extracts show antioxidant and antiproliferative activities against human cancer cells. Another study reported that the passion fruit peels are rich in high methoxyl pectin, which was extracted at $\mathrm{pH}$ 2.0 , peel to solvent ratio of $1: 30(\mathrm{w} / \mathrm{v})$, extraction temperature of $98.7^{\circ} \mathrm{C}$ and time of extraction of $60 \mathrm{~min}$, where the solvent was taken as acidified water with hydrochloric acid (Kulkarni and Vijayanand 2010). Sood and Gupta (2015) used the ethanolic solution to extract bioactive compounds from pomegranate peel. They reported that the extracted compound is a good source of phenolic and flavonoids content (quercetin) which was opted at the conditions of solid to solvent ratio of 1:30, the temperature of $50{ }^{\circ} \mathrm{C}$, and the time of extraction of $45 \mathrm{~min}$.

In the same way, Fidelis et al. (2020) utilized the solvent extraction method, with the combination of three solvents, i.e., ethanol, water, and propane, to extract the bioactive compounds from camu-camu seed. The vescalagin and castalagin compounds were extracted, showing high antioxidant, antiproliferative and cytotoxic capacities against A549 and HCT8 cancer cells. It also showed antimicrobial effects, protected human erythrocytes against haemolysis, inhibited $\alpha$-amylase and $\alpha$-glucosidase enzymes and presented in vitro antihypertensive effects.

\section{Enzyme-assisted extraction (EAE)}

The enzyme-assisted extraction is usually applied to those bioactive compounds which are not easily extracted through conventional techniques and are tightly bonded in the cell wall. In this technology, the cell wall is hydrolyzed by enzymes, and due to this, the bioactive compounds present inside the cell plasma oozes out from the cell (Nadar et al. 2018; Panja 2018). Some of the most common and frequently used enzymes for this purpose are polygalacturonase, xylanase pectin esterase, polygalacturonase, cellulase, hemicellulase, amylase, b-galactosidase, protease, 1,4-glycosidase, tannase, papainase, and tyrosinase (Barbosa et al. 2020; Liu et al. 2016).
The enzyme plays a significant role in the extraction process. It binds with the cell wall's active site, which is composed of a polysaccharide-lignin network and hydrolyses the polysaccharide and lipid body structures by breaking glycoside bonds in the cell wall and proteolytic bonds in middle lamella (Grassino et al. 2020; Zhang et al. 2019). Thus, the bioactive compounds present inside the cell and middle lamella is extracted through the cell wall. The selection of enzymes for extraction depends on the isolation of target compounds that either degrade the pectin, polysaccharides or break the cell wall to isolate them (Azmir et al. 2013; Lombardelli et al. 2020). Even though this method is better suited than conventional technologies, the cost of enzymes and high extraction time are some disadvantages.

Hamid and Ismail (2020) found that the seed of dates has carbohydrates composed of lignin, cellulose, and hemicelluloses. They examined the waste and showed that lignin and cellulose could be hydrolyzed by enzymes to form fermented sugars with the highest yield of $31 \mathrm{~g} / \mathrm{L}$ at the optimum condition of $120 \mathrm{FPU} / \mathrm{g}$ of enzyme for $6 \mathrm{~h}$, at $45^{\circ} \mathrm{C}$, where the enzyme was taken as cellulase. Similarly, Vasco-Correa and Zapata (2017) reported that the pectin extracted from passion fruit peel using proto-pectinase enzyme has a better yield than the conventional chemical extraction. The pectin was extracted about $40 \%$ higher by applying an enzyme of $30 \mathrm{U} / \mathrm{ml}$ at $\mathrm{pH}$ of 3 and $37^{\circ} \mathrm{C}$. Similarly, the pomegranate seed from the juice industry has a high percentage of fatty acid (22.9\%), protein $(13.2 \%)$, and dietary fibers $(97.2 \%)$. The enzyme-assisted extraction when using protease enzyme at a concentration of $50 \mathrm{U} / \mathrm{g}$ for $14 \mathrm{~h}$, at $45^{\circ} \mathrm{C}$ and $\mathrm{pH} 7.2$ is found to have a higher yield of oil recovery (4\%) than the Soxhlet extraction (Talekar et al. 2018).

$\mathrm{Xu}$ et al. (2014) conducted a study comparing polysaccharide extraction from grape peel using solvent extraction (using ethanol) and with a combination of enzymes, such as cellulase, pectinase, and $\beta$-glucosidase. The study reported that the enzyme-assisted extraction required less time for a higher yield of pectin, which contains phenolic compounds, anthocyanin than the solvent extraction. Another study reveals that combining enzyme-assisted extraction and supercritical extraction can be a better technological combination for obtaining a better yield of polyphenols, such as vanillic, ferulic, and syringic acid from pomegranate peels. The mixture of enzymes (pectinase, protease, and cellulase) in the ratio of 25:25:50 at a concentration of 3.8\%, temperature $49^{\circ} \mathrm{C}$, time of treatment $85 \mathrm{~min}$ and $\mathrm{pH}$ of 6.7 caused the highest yield of extract containing phenolic compounds (Mushtaq et al. 2015). Furthermore, the pineapple peel is a source of vinegar in sugar production, which can also 
be extracted with enzymes, such as cellulase, hemicellulase, and pectinase (Roda et al. 2016).

\section{Supercritical fluid extraction (SFE)}

Due to the degradation of natural thermosensitive compounds, extraction using enzymes and solvents loses popularity among industries. These technologies are now mainly replaced by SFE technology, also known as green technology. It is an advanced form of solvent extraction technology, where different solvents are used as fluid under pressure ranging from about 200 to 400 bar and temperature ranging from 40 to $60^{\circ} \mathrm{C}$ (Gullón et al. 2020; Pinto et al. 2020). Among the solvents, toluene, ethylene, ammonia, and carbon dioxide are primarily used due to their availability, environment safety, non-explosibility, non-toxicity, less expensive, and easily removable properties (Al-Otoom et al. 2014; Vardanega et al. 2019).

The fluid subjected to biomass is in the supercritical condition, where it behaves, such as both liquid and gas. Mainly carbon dioxide is used as the fluid; it is converted to the supercritical stage beyond its critical point by applying a pressure of $7.38 \mathrm{MPa}$ and temperature of $31{ }^{\circ} \mathrm{C}$ (Al-Otoom et al. 2014; Ding et al. 2020). In this condition, the solvent's polarity decreases, and solubility increases, helping the fluid penetrate the cell wall quickly. The bioactive compounds dissolved with this supercritical fluid and extracted along with it (Torres-Ossandón et al. 2018). There are different types of equipment and processes used for SFE, which are described in Table 1. Sometimes, modifiers are used with the fluids to increase their polarity, extracting compounds with high polarity (Gallego et al. 2019).

Cruz et al. (2017) examined and compared the extraction of phenolic compounds from jelly palm seeds with the help of soxhlet extraction, ultrasound-assisted extraction, and SFE with $\mathrm{CO}_{2}$ as solvent and ethanol as cosolvent. The study found that the SFE has improved the extraction yield with carbon dioxide, ethanol, and water. Similarly, the SFE was found superior over soxhlet extraction in extracting oil composed of fatty acid and phenolic compounds from guava seed at optimum conditions of temperature $52^{\circ} \mathrm{C}$ and $35.7 \mathrm{MPa}$ (density of $\mathrm{CO}_{2}: 895 \mathrm{~kg} /$ $\mathrm{m}^{3}$ ) at a constant flow of $30 \mathrm{~g} \mathrm{CO}_{2} / \mathrm{min}$ for $150 \mathrm{~min}$. During extraction, linoleic and oleic acid is found to be the major fatty acid components in guava seed oil. Vanillin, cinnamaldehyde, vanillic acid, cinnamic acid, phytosterols, tocopherols, $\beta$-sitosterol, and $\gamma$-tocopherol, was the primary phenolic compound found in the oil (NarváezCuenca et al. 2020). Cuco et al. (2019) examined that a higher yield of linoleic, oleic, and linolenic acid was obtained when oil was extracted from the pumpkin seed using SFE technology at the optimum conditions of 22
Mpa and $333 \mathrm{~K}$ than the ultrasound-assisted extraction (power of $165 \mathrm{~W}$ and frequency of $25 \mathrm{kHz}$ ) with the solvent as n-hexane. Similarly, the yield of oil obtained from the apple seed was higher through SFE technology than soxhlet extraction. At $24 \mathrm{MPa}$ pressure, $40{ }^{\circ} \mathrm{C}$ temperature, $1 \mathrm{~L} / \mathrm{h}$ of carbon dioxide flow rate and $140 \mathrm{~min}$ of treatment time, the yield of oil was $20.5 \%$, where at $4 \mathrm{~h}$ of soxhlet extraction the yield of oil was $22 \%$ but the difference between both oil was the percentage of unsaturated fatty acid present in it (Ferrentino et al. 2020).

Natolino and Da Porto (2019) explained the extraction of oil, which contains the phenolic compound punicic acid, from pomegranate seed using SFE at $60^{\circ} \mathrm{C}$ and 320 bars. The study also measured the solubility of oil to find out its antioxidant activity. The solubility in $\mathrm{SC}-\mathrm{CO}_{2}$ is a characteristic property of the sample in the form of fatty acid content and oxygen stability. In the same way, different studies found that SFE using $\mathrm{CO}_{2}(2 \mathrm{~g} / \mathrm{min})$ was successful in extracting phenolic compounds, such as terpene, $\gamma$-element, germacrene, ellagitannins, and flavanols from Brazilian cherry at high pressure and low temperature and the extraction at a pressure at $25 \mathrm{MPa}$, the temperature at the inlet to the reactor $40^{\circ} \mathrm{C}$, the mass of raw material loaded into the reactor $300.0 \mathrm{~g}$. Flow rate $\mathrm{CO}_{2} 6.0-7.0 \mathrm{~kg}$ caused the higher yield of phenolic compounds from strawberry seeds (e Santos et al. 2015; Grzelak-Błaszczyk et al. 2017). This technology also helped in recovering maximum oil from rosehip seed at the optimum conditions of pressure $30 \mathrm{MPa}$, the temperature of $40{ }^{\circ} \mathrm{C}$, concentration $0.75 \mathrm{~mL} / \mathrm{min}$, particle size $355<\mathrm{Dp}<500 \mu \mathrm{m}$, and time of $150 \mathrm{~min}$ (Salgin et al. 2016). Another study from Marić et al. (2020) suggested that the SFE process at optimum conditions of pressure (300 bar), temperature $\left(50{ }^{\circ} \mathrm{C}\right)$, concentration $(0.3 \mathrm{~kg}$ $\mathrm{CO}_{2} / \mathrm{h}$ ) and treatment time $(4 \mathrm{~h})$ is superior over all other soxhlet extraction processes for $8 \mathrm{~h}$ in the recovery of oil from raspberry seed which is composed of a high amount of $\omega-3$ fatty acids as well as tocopherols and antioxidants. Furthermore, Gustinelli et al. (2018) also successfully extracted vitamin E containing oil from bilberry seed using SFE with $\mathrm{CO} 2$ as the solvent at the optimum conditions of $20 \mathrm{MPa}$ and $60^{\circ} \mathrm{C}$ for $80 \mathrm{~min}$.

\section{Subcritical fluid extraction (SWE)}

The modifiers may increase the cost of SFE technology and makes it uneconomical. Hence another method of extraction, SWE, is popular as a replacement for SFE. Here, the fluid is used as a solvent in its subcritical condition between the boiling and critical point (Essien et al. 2020; Zhang et al. 2019). Several polar solvents are used in this process (Table1). However, water is most commonly used among these solvents due to its lower 
basicity, high polarity, high diffusivity, and environmental safety (Essien et al. 2020).

The polarity and viscosity of water decrease with rising temperature from 100 to $374{ }^{\circ} \mathrm{C}$ and pressure from 1 to $22 \mathrm{MPa}$. Its solubility increases, which helps extract the bioactive compounds by diffusion, partitioning, equilibrium, or convection. SWE is a cheap and clean technique; however, oxidation and hydrolysis of the pectin chain were reported in a few situations (Gallego et al. 2019; Zhang et al. 2020).

Rodrigues et al. (2019) showed that the extracts from papaya seed could be separated with subcritical water extraction at $150{ }^{\circ} \mathrm{C}$ in $5 \mathrm{~min}$ and found that ferulic, mandelic, and vanillic acids are the main components of phenolic groups, which are significantly higher than the soxhlet extraction at $40{ }^{\circ} \mathrm{C}$ for the time of $6 \mathrm{~h}$. Another study shows that sweet passion fruit seed oil contains unsaturated fatty acid (86.36\%) and tocopherols, potent antioxidants used in the chemical and pharmaceutical industries. This oil extracted using subcritical propane extraction at $60^{\circ} \mathrm{C}$ and $6 \mathrm{MPa}$ pressure provided a significantly higher yield than soxhlet extraction at $65^{\circ} \mathrm{C}$ for $4 \mathrm{~h}$, where the solvent was taken $\mathrm{n}$-hexane (Pereira et al. 2017). A similar study on extraction of polyphenols from grape seed and peel using subcritical water extraction in semi-continuous mode reveals that yield in total polyphenol of 44.3 to $77 \mathrm{mg} / \mathrm{g}$ and 44 to $124 \mathrm{mg} / \mathrm{g}$ from peels and seed, respectively, was obtained when the water was subjected to a temperature of $80-120{ }^{\circ} \mathrm{C}$ and pressure of $100 \mathrm{MPa}$ (Duba et al. 2015).

Liew et al. (2018) described pectin extraction from pomelo fruit peel using subcritical water extraction technology in a dynamic mode. During the study, the obtained yield of low methoxyl pectin was $18.8 \%$ in the optimized condition of 30 bar pressure and temperature of $120^{\circ} \mathrm{C}$. A similar study on citrus Juno's fruit peel, which contains a high amount of dietary fiber, oils, pectin, hemicelluloses, and cellulose, reveals that $78 \%$ of pectin and $80 \%$ hemicelluloses and cellulose were separated from the peels after subcritical water extraction in a semi-continuous mode, where the optimum conditions were at a temperature of $200{ }^{\circ} \mathrm{C}$, pressure $20 \mathrm{Mpa}$ in each water flow rate $2.1,3.5$, and $7.0 \mathrm{~mL} / \mathrm{min}$ (Tanaka et al. 2012).

\section{Microwave-assisted extraction (MAE)}

Despite the risk of oxidation, MAE is one of the most promising technology for obtaining bioactive compounds from fruit by-products. This technology uses microwave energy as a generator of heat, where the samples are subjected directly or indirectly. The microwave spectrum is the electromagnetic wave of combined electric and magnetic fields ranging from $300 \mathrm{MHz}$ to $300 \mathrm{GHz}$ and wavelength from $1 \mathrm{~cm}$ to $1 \mathrm{~m}$. However, in MAE, the most frequently used frequency ranges from 915 to $2450 \mathrm{MHz}$, and wavelength ranges from 12 to $20 \mathrm{~cm}$ (Ciriminna et al. 2016; Garavand et al. 2019).

The microwave radiation applied to the sample generates heat by rotation and displacement of ions and molecules, which causes localized heating from inside to outside (Maran et al. 2015; Mena-García et al. 2019). Dipole rotation and ionic conduction are the leading cause of mass and heat transfer from cell to cell matrix. The bonds between tissues and molecules are broken by water evaporation, causing the extraction of volatile and non-volatile compounds. Upon microwave treatment, the cell wall ruptures so that the bioactive compounds present inside the cell wall can penetrate out of the cell (Adetunji et al. 2017). The moisture present in the biomass and microwave power causes rapid heating and rapid extraction of compounds from the product (MenaGarcía et al. 2019).

Al-Dhabi and Ponmurugan (2020) proved that the Jamun seed contains a high amount of polysaccharides which can be extracted through MAE. In the study, the polysaccharides yield obtained $4.71 \%$ at a microwave power of $515 \mathrm{~W}, \mathrm{pH}$ of 3.2, and time of $3.1 \mathrm{~min}$, and SL ratio of 1:15 g/ml. Similarly, Torres-León et al. (2017) showed that the high amount of bioactive compounds from mango seed could be extracted through MAE at optimum conditions of solid to solvent ratio $1 / 60 \mathrm{~g} / \mathrm{mL}$, treatment temperature of $75{ }^{\circ} \mathrm{C}$, and extraction cycle of 2 cycles, where the solvent was taken as ethanol. The study also reported that the primary antioxidants found in mango seed are ethyl gallate, pent-O-galloyl-glucoside (PGG), and hamnetin-3-[6-2-butenoil-hexoside]. Furthermore, the dragon fruit peel contains a methoxyl group of pectin which can be extracted maximum using MAE with an operating condition of $450 \mathrm{~W}$ power and $5 \mathrm{~min}$, then CE processes at $85^{\circ} \mathrm{C}$ for $1 \mathrm{~h}$ treatment time. The solvent was taken as water mixed with $0.05 \mathrm{M}$ of nitric acid (Tongkham et al. 2017).

Avocado seeds are agro-industrial residues that can be used as the source of antioxidants, phenolic acids, procyanidins dimer $\mathrm{B}$, catechin, epicatechin. Araújo et al. (2020) showed that a maximum amount of bioactive compounds could be extracted from avocado seeds using microwave-assisted solvent extraction with two different solvents, acetone $\left(72.18{ }^{\circ} \mathrm{C}\right.$ and $\left.19.01 \mathrm{~min}\right)$ and ethanol $\left(71.64{ }^{\circ} \mathrm{C}\right.$ and $\left.14.69 \mathrm{~min}\right)$, respectively. Likewise, watermelon peel contains a considerable amount of pectin, which can be extracted with maximum yield through MAE at a microwave power of $477 \mathrm{~W}$, the irradiation time of $128 \mathrm{~s}, \mathrm{pH}$ of 1.52, and a solid/liquid ratio of 
$1: 20 \mathrm{~g} / \mathrm{mL}$, where the distilled water was taken as solvent (Maran et al. 2014).

The pineapple peel is a good source of pectin and polyphenolic compounds, which can be extracted through MAE at a power of $420 \mathrm{~W}$ and irradiation time of $30 \mathrm{~min}$, compared with CE done for 60 min (Rodsamran and Sothornvit 2019b). Similarly, the peel of mahkota dewa, a well-known medicinal plant, is composed of phenolic compounds which can be successfully extracted using MAE technology with a yield of $61.25 \%$ at a microwave power of $300 \mathrm{~W}$ in $1 \mathrm{~min}$ at $80^{\circ} \mathrm{C}$, where the solvent was taken as water and solid to solvent ratio was $60 \mathrm{~g} / \mathrm{ml}$ (Alara et al. 2019).

\section{Ultrasound-assisted extraction (UAE)}

UAE uses the sound energy produced by ultrasonic waves with frequencies ranging from 20 to $100 \mathrm{kHz}$ (Belwal et al. 2020; Dzah et al. 2020; Saifullah et al. 2020). Because of its advantages, this emerging technology is also called green technology. The major drawback of this process is the number of repetitions required to complete the extraction process, resulting in a lot of time and energy consumption (Carrillo-Hormaza et al. 2020; Chakraborty et al. 2020).

The cavitation is the leading cause of extraction, which is generally generated by the ultrasonication process ranging from 20 to $40 \mathrm{kHz}$. Cavitation is the phenomenon in which the microbubbles are formed, enlarged, and imploded. The generation of microbubbles is caused by ultrasonic waves of continuous compression and the rarefaction process. This cavitation helps in the mass transfer process between the liquid extracting medium and the solid plant materials for enhancing the extraction process (Alirezalu et al. 2020; Grassino et al. 2020; Meregalli et al. 2020).

During UAE, the negative pressure formed in rarefaction causes cavitation, leading to the formation of bubbles that collapses near the solid materials. Localized heating due to the high speed of the liquid jet causes fragmentation of brittle materials. The desired compounds are eroded from the plant cell when the cell gets ruptured by turgor pressure created by the cell wall because of the solvent medium's entry (Chen et al. 2019; Machado et al. 2019; Ojha et al. 2020). Different mechanisms are responsible independently for the rupturing of the cell wall, such as fragmentation, erosion, sonoporation, sono-capillary effect, local shear stress, and detexturization (Chemat et al. 2017).

Rambutan fruit peel can be a source of polysaccharides that could be extracted through the UAE. Maran and Priya (2014) proved that the rambutan fruit peel could be a good source of polysaccharides which can be extracted with its maximum yield using the UAE technique at the optimum liquid to solid ratio of $32: 1 \mathrm{ml}: \mathrm{g}$, ultrasonic power of $110 \mathrm{~W}$, extraction temperature of $53{ }^{\circ} \mathrm{C}$ and extraction time of $41 \mathrm{~min}$. Similarly, this technology successfully extracted the polysaccharides from the jujube seeds at the optimum temperature of $83.1{ }^{\circ} \mathrm{C}$, time of $100 \mathrm{~min}$, ultrasonic power of $140 \mathrm{~W}$, and water-material ratio $33.5 \mathrm{~mL} / \mathrm{g}$, which have antitumor activity (Wu et al. 2019). Likewise, UAE was found superior to conventional and soxhlet extraction technologies for extracting the bioactive compounds with higher antioxidant activity (1.2 times higher) from Jamun seed powder at the optimal condition of 12 min extraction time, solid to water ratio $1: 15$, temperature $35{ }^{\circ} \mathrm{C}$, power $125 \mathrm{~W}$, and duty cycle 60\% (Mahindrakar and Rathod 2020).

Another study on baobab seed which has a high amount of phenolic compounds reported that the UAE process at $20 \mathrm{~min}, 30 \%$ amplitude, $60{ }^{\circ} \mathrm{C}$ temperature, and $30 \mathrm{ml} / \mathrm{g}$ solvent to solid ratio results in an extract that contains a high amount of flavonoid contents and antioxidant activity than the conventional solvent extraction (Ismail et al. 2019). A similar study by Raj and Dash (2020) described that the UAE is better among other technologies in extracting pectin from dragon peel. The extract contained a higher yield of phenolic compounds, antioxidants, and betacyanin of the optimum conditions at an ultrasonic temperature of $60{ }^{\circ} \mathrm{C}$, solvent to solid ratio $25: 1 \mathrm{~mL} / \mathrm{g}$, solvent concentration $60 \%$, and ultrasonic treatment time of $20 \mathrm{~min}$. Moreover, the highest amount of total phenolic content $(1493.01 \mathrm{mg}$ GAE/100 g) was extracted from mango peels using UAE technology because of higher ultrasound intensity. The solvent was taken as a blend of ethanol-acetone (Martínez-Ramos et al. 2020).

Furthermore, maximum polysaccharides yield of $15.94 \%$ was obtained from canister seed when UAE was applied at an ultrasonic temperature of $79{ }^{\circ} \mathrm{C}$, ultrasonic time of $69 \mathrm{~min}$, and liquid to the material ratio of $41 \mathrm{ml} / \mathrm{g}$, where the solvent was taken as water (Ma et al. 2020). Similarly, the strawberry peel is rich in bioactive compounds beneficial to human health, such as phenolic compounds, carotenoids, flavonoids, and anthocyanins which can be extracted by the UAE technique. The anthocyanin recovered from the peel was $12 \%$ more in UAE at optimum conditions of time $90 \mathrm{~min}$ and frequency of $50 \mathrm{kHz}$ than the CE process (maceration) at time of $120 \mathrm{~min}$, with constant ethanol concentration (90\%), $\mathrm{pH} 1.5$, and sample mass/solvent volume ratio $(1 \mathrm{~g} / 10 \mathrm{ml})$ (Meregalli et al. 2020).

\section{Pulsed-electric field-assisted extraction (PEFAE)}

The PEFAE can be considered a novel extraction technology for bioactive compound extraction due to purity, less energy requirement, and environment-friendly solvent 
usage. It is also called a non-thermal extraction process, because the natural compounds are recovered at a minimal temperature without losing quality and nutritional value (Andreou et al. 2020; El Kantar et al. 2018a). Electroporation is the primary mechanism behind pulsed electric field extraction. In the process of PEFAE, the electrical energy is applied for the creation of nano/ micro-poration of the cell membrane so that the bioactive compounds present inside the cell plasma could extract out of it (Puértolas et al. 2013; Shorstkii et al. 2020). The electric pulses cause the transfer of ions and molecules from inside the cell towards the cell membrane (phospholipids bounded molecule), acting as an insulator (Plazzotta et al. 2021).

In a study, the apple peels were treated under the pulsed electric field with different electric intensities and times to extract the phenolic compounds. The extraction is analyzed concerning the electrical conductivity (disintegration index) and confocal laser scanning microscopy (microscopic cell disintegration index). The results reported that the extraction was dependent on the cell integration index and the electric field intensity. The study also confirmed that the higher the intensity $(1200 \mathrm{~V} / \mathrm{cm})$ at constant cell integration constant, the higher the soluble matter recovery (Wang et al. 2020). Similarly, Parniakov et al. (2015) reported the extraction of bioactive compounds from papaya seeds by PEFAE. Here, the recovery was influenced by undesirable chemicals and free radicals when the extraction was done by high voltage electric discharge (HVED). The extract obtained from PEFAE along with solvent aqueous extraction about $50{ }^{\circ} \mathrm{C}, \mathrm{pH}-7$ and time of $5 \mathrm{~h}$ had a higher yield (200\%) containing $20 \%$ higher antioxidant capacity than CE. Likewise, pear peel is a good source of red colour compounds, such as betanin and isobetanin, which can replace the synthetic colourings in the industry. Koubaa et al. (2016) proved that the maximum yield of colour has happened during the PEFAE at the intensity of $20 \mathrm{kV} / \mathrm{cm}$ along with 300 pulses followed by supplementary aqueous extraction of $1 \mathrm{~h}$ as compared to the conventional grinding followed by supplementary aqueous extraction of $24 \mathrm{~h}$.

Another study by Parniakov et al. (2016) showed that the yield of antioxidants, protein, and carbohydrates from the mango peels was maximum when PEFAE at intensity $13.3 \mathrm{kV} / \mathrm{cm}$ was combined with aqueous extraction at $50{ }^{\circ} \mathrm{C}$ temperature for $5 \mathrm{~h}$ at six $\mathrm{pH}$, which was found higher than the aqueous extraction at temperature $60{ }^{\circ} \mathrm{C}$ and $\mathrm{pH}$ 6. However, the yield was comparatively less when extracted separately using PEFAE or using aqueous extraction. Similarly, Luengo et al. (2013) conveyed that an electric field treatment of intensity $7 \mathrm{kV} / \mathrm{cm}$ with a pulse rate of 20 in 60 microseconds was found successful in extracting the polyphenols and flavonoid compounds from orange peel.

\section{Combination of extraction (CE) process}

The extraction technologies mentioned above can also be used in combinations to further reduce the extraction time, increase the extraction yield, and overcome the limitations of the single technologies (Zuin and Ramin 2018). The pre-treatment of fruit by-products using the microwave or ultrasound or enzyme before any $C E$ process for the rapid breakdown of cell walls is one of the commonly followed combined extraction treatments. Similarly, two or more emerging extraction processes can also be used in combinations, such as SFE and UAE, MAE and solvent extraction, enzyme application before treatment of PEF, and supercritical fluid treatment before MAE followed by supplementary solvent extraction and so on (Dias et al. 2019). A few examples of combined extraction processes for bioactive compounds recovery from fruit by-products are summarized in Table 3.

\section{Conclusion}

This review describes both conventional and emerging techniques used to extract bioactive compounds from the by-products of fruit processing industries. The primary process parameters, advantages, disadvantages, and applications of each technology were explained in detail. Moreover, the bioactive compounds extracted from extraction technologies were characterized in chromatographic and spectrophotometric methods. With an increase in the number of fruit processing industries, the number of by-products from these industries also increases. Management of these by-products is a considerable burden for the industries, and the improper disposal of these by-products can create significant harm to the environment. Hence, its utilization as a source of bioactive compounds will increase industries' financial status and decrease their burden of waste management. Improvement in extraction technology with lesser or no use of solvents will significantly impact a sustainable bioprocess. In addition, the characterization of bioactive compounds by rapid, sensitive, and cost-effective methods helps for the utilization and incorporation in the various field. Industrial by-products can be converted into a potential source of bioactive compounds. The compounds extracted from it can be incorporated into various products in the pharmaceutical and food industries. 
Table 3 Combination of extraction technologies for the recovery of bioactive compounds from fruit by-products

\begin{tabular}{|c|c|c|c|c|c|}
\hline SI. No. & Name of the by-product & $\begin{array}{l}\text { Combination } \\
\text { of extraction } \\
\text { processes }\end{array}$ & Optimized condition & Bioactive compounds & References \\
\hline 1 & $\begin{array}{l}\text { Vitis vinifera } \\
\text { (Grape) peel }\end{array}$ & UAE + PEFFAE & $\begin{array}{l}\text { Ultrasonic energy with } 50^{\circ} \mathrm{C} \\
\text { with a pulse of flow } 290 \mathrm{~L} / \mathrm{h} \text {, } \\
\text { diameter of chamber } 25 \mathrm{~mm} \text {, } \\
\text { gap } 26 \mathrm{~mm}, 25 \mathrm{kV} \text { voltage }\end{array}$ & $\begin{array}{l}\text { Anthocyanin } \\
\text { Flavonoids }\end{array}$ & $\begin{array}{l}\text { (Medina-Meza and Barbosa- } \\
\text { Cánovas 2015) }\end{array}$ \\
\hline 2 & $\begin{array}{l}\text { Litchichinensis } \\
\text { (Litchi) seed }\end{array}$ & UAE + PEFAE & $\begin{array}{l}30 \% \text { aqueous ethanol, } \\
62.66 \mathrm{~mL} / \mathrm{g} \text { ratio of liquid: } \\
\text { solid, } 123 \mathrm{~mL} / \mathrm{min} \text { flow veloc- } \\
\text { ity, } 276 \mathrm{~W} \text { ultrasonic power, } \\
47^{\circ} \mathrm{C} \text { ultrasonic temperature, } \\
\text { discharge voltage } 14 \mathrm{kV}\end{array}$ & Saponins & (Fan et al. 2020) \\
\hline 3 & Citrus aurantiifolia (Lime) peel & $M A E+U A E$ & $\begin{array}{l}\text { Microwave power } 140 \mathrm{~W} \text { with } \\
55 \% \text { ethanol } 45 \mathrm{~s} \text { and ultra- } \\
\text { sonic energy of } 38 \% \text { amplitude } \\
\text { for } 4 \text { min }\end{array}$ & $\begin{array}{l}\text { Phenolic compounds, } \\
\text { Antioxidants }\end{array}$ & $\begin{array}{l}\text { (Rodsamran and Sothornvit } \\
\text { 2019a) }\end{array}$ \\
\hline 4 & $\begin{array}{l}\text { Passiflora edulis } \\
\text { (Passion) seed }\end{array}$ & $S P E+U A E$ & $\begin{array}{l}\text { Ultrasonic power of } 160 \mathrm{~W} \\
\text { and at } 40^{\circ} \mathrm{C} \text { and pressure of } \\
16 \mathrm{MPa} \text { in SFE }\end{array}$ & $\begin{array}{l}\text { Tocopherols } \\
\text { Tocotrienol }\end{array}$ & (Barrales et al. 2015) \\
\hline 5 & $\begin{array}{l}\text { Citrus sinensis } \\
\text { (Orange) peel }\end{array}$ & $E A E+P E F A E$ & $\begin{array}{l}\text { The high voltage of energy } \\
\text { input of } 222 \mathrm{~kJ} / \mathrm{kg} \text { with enzy- } \\
\text { matic hydrolysis viscozyme of } \\
12 \mathrm{FBGU} / \mathrm{g}\end{array}$ & $\begin{array}{l}\text { Polyphenols, } \\
\text { Reducing sugars }\end{array}$ & (El Kantar et al. 2018b) \\
\hline 6 & $\begin{array}{l}\text { Punica granatum } \\
\text { (Pomegranate) seed }\end{array}$ & $\mathrm{SPE}+\mathrm{MAE}+\mathrm{CE}$ & $\begin{array}{l}\text { Microwave radiation of } 250 \mathrm{~W} \\
\text { with } 6 \text { min and then by SFE } \\
\text { and Soxhlet extraction }\end{array}$ & Punicic acid & (Đurđević et al. 2017) \\
\hline 7 & $\begin{array}{l}\text { Spondias tuberose } \\
\text { (Umbu) seed }\end{array}$ & $S P E+U A E$ & $\begin{array}{l}\text { SFE at } 40^{\circ} \mathrm{C} \text { with } 15 \mathrm{Mpa} \\
\text { and then ultrasonic power of } \\
500 \mathrm{~W} \text { with } 4 \text { min and } 1: 30 \\
\text { S/L ratio }\end{array}$ & $\begin{array}{l}\text { Free fatty acid, } \\
\text { Phenolic compounds }\end{array}$ & (Dias et al. 2019) \\
\hline 8 & $\begin{array}{l}\text { Litchichinensis } \\
\text { (Litchi) peel }\end{array}$ & $M A E+U A E$ & $\begin{array}{l}\text { MAE in } 70{ }^{\circ} \mathrm{C} \text { in } 4 \text { min of } \\
\text { extraction with } 40: 1 \text { solvent: } \\
\text { material ratio and UAE in } 3 \text { min } \\
\text { of extraction and chloroben- } \\
\text { zene as a solvent }\end{array}$ & Pyrethroid & (Wang et al. 2018) \\
\hline
\end{tabular}

\section{Abbreviations}

CE: Conventional extraction; EAE: Enzyme-assisted extraction; SFE: Supercritical fluid-assisted extraction; SWE: Subcritical water-assisted extraction; MAE: Microwave-assisted extraction; UAE: Ultrasound-assisted extraction; PEFAE: Pulsed electric field-assisted extraction; DPPH: 2,2-Diphenyl-1-picryl-hydrazylhydrate; ABTS: 2,2'-Azino-bis (3-ethylbenzothiazoline-6-sulfonic acid); FRAP: Ferric reducing ability of plasma; ORAC: Oxygen Radical Absorbance Capacity; HPLC: High-pressure liquid chromatography; TLC: Thin liquid chromatography; GC: Gas chromatography; MS: Mass chromatography; MIC: Minimum inhibitory concentrations; DAD: Diode-Array Detection; ESI: Electrospray ionization.

\section{Acknowledgements}

Not applicable.

\section{Authors' contributions}

AP: Format analysis, methodology, resources, validation,writing-original draft, writing-review \& editing. SA: Data curation, formal analysis, methodology, resources, validation, visualization, writing-review \& editing. RCP: Conceptualization, investigation, supervision, validation, writing-review \& editing. All authors read and approved the final manuscript.

\section{Funding}

This research did not receive any specific grant from funding agencies in the public, commercial, or not-for-profit sector.
Availability of data and materials

Not applicable.

\section{Declarations}

Ethics approval and consent to participate

Not applicable.

\section{Consent for publication}

Not applicable.

\section{Competing interests}

The authors declare that they have no competing interests.

Received: 29 October 2021 Accepted: 19 January 2022

Published online: 18 February 2022

\section{References}

Adetunji LR, Adekunle A, Orsat V, Raghavan V (2017) Advances in the pectin production process using novel extraction techniques: a review. Food Hydrocoll 62:239-250 
Akhtar S, Ismail T, Fraternale D, Sestili P (2015) Pomegranate peel and peel extracts: chemistry and food features. Food Chem 174:417-425

Alara OR, Mudalip SKA, Abdurahman NH, Mahmoud MS, Obanijesu EO-O (2019) Data on parametric influence of microwave-assisted extraction on the recovery yield, total phenolic content and antioxidant activity of Phaleria macrocarpa fruit peel extract. CDC 24:100277

Al-Dhabi NA, Ponmurugan K (2020) Microwave assisted extraction and characterization of polysaccharide from waste jamun fruit seeds. Int J Biol Macromol 152:1157-1163

Alirezalu K, Pateiro M, Yaghoubi M, Alirezalu A, Peighambardoust SH, Lorenzo JM (2020) Phytochemical constituents, advanced extraction technologies and techno-functional properties of selected Mediterranean plants for use in meat products. A comprehensive review. Trends Food Sci Technol 100:292-306

Al-Otoom A, Al-Asheh S, Allawzi M, Mahshi K, Alzenati N, Banat B, Alnimr B (2014) Extraction of oil from uncrushed olives using supercritical fluid extraction method. J Supercrit Fluids 95:512-518

Altemimi A, Lakhssassi N, Baharlouei A, Watson DG, Lightfoot DA (2017a) Phytochemicals: extraction, isolation, and identification of bioactive compounds from plant extracts. Plants 6(4):42

Andreou V, Dimopoulos G, Dermesonlouoglou E, Taoukis P (2020) Application of pulsed electric fields to improve product yield and waste valorization in industrial tomato processing. J Food Eng 270:109778

Araújo RG, Rodriguez-Jasso RM, Ruiz HA, Govea-Salas M, Pintado ME, Aguilar CN, Products (2020) Process optimization of microwave-assisted extraction of bioactive molecules from avocado seeds. Ind Crops Prod 154:112623

Ares AM, Valverde S, Bernal JL, Nozal MJ, Bernal J (2018) Extraction and determination of bioactive compounds from bee pollen. J Pharm Biomed Anal 147:110-124

Arrutia F, Adam M, Calvo-Carrascal MÁ, Mao Y, Binner E (2020) Development of a continuous-flow system for microwave-assisted extraction of pectinderived oligosaccharides from food waste. Chem Eng J 395:125056

Aruna P, Venkataramanamma D, Singh AK, Singh R (2016) Health benefits of punicic acid: a review. Compr Rev Food Sci Food Saf 15(1):16-27

Azmir J, Zaidul ISM, Rahman M, Sharif K, Mohamed A, Sahena F, Jahurul M, Ghafoor K, Norulaini N, Omar A (2013) Techniques for extraction of bioactive compounds from plant materials: a review. J Food Eng 117(4):426-436

Babbar N, Oberoi HS (2014) Potential of agro-residues as sources of bioactive compounds. In: Biotransformation of waste biomass into high value biochemicals, Springer, pp. 261-295.

Bailey CN (2015) Separation and identification of bioactive compounds from Oplopanax horridus.

Barbosa JR, dos Santos Freitas MM, da Silva Martins LH, de Carvalho Junior RN (2020) Polysaccharides of mushroom Pleurotus spp.: new extraction techniques, biological activities and development of new technologies. Carbohydr Polym 229:115550

Barrales FM, Rezende CA, Martínez J (2015) Supercritical CO2 extraction of passion fruit (Passiflora edulis sp.) seed oil assisted by ultrasound. J Supercrit Fluids 104:183-192

Belwal T, Chemat F, Venskutonis PR, Cravotto G, Jaishwal DK, Bhatt ID, Devkota HP, Luo Z (2020) Recent advances in scaling-up of non-conventional extraction techniques: Learning from successes and failures. Trends Analyt Chem 127:115895

Bressani R, Rodas B, Ruiz A (2009) La composición química, capacidad antioxidativa y valor nutritivo de la semilla de variedades de aguacate. Fondo Nacional de Ciencia y Tecnología-FONACYT, Universidad del Valle de Guatemala-UVG, Tegucigalpa (Guatemala)

Carrillo-Hormaza L, Duque L, López-Parra S, Osorio E (2020) High-intensity ultrasound-assisted extraction of Garcinia madruno biflavonoids: Mechanism, kinetics, and productivity. Biochem Eng J 161:107676

Chakraborty S, Uppaluri R, Das C (2020) Optimization of ultrasound-assisted extraction (UAE) process for the recovery of bioactive compounds from bitter gourd using response surface methodology (RSM). Food Bioprod Process 120:114-122

Chemat F, Vian MA, Cravotto GJI (2012) Green extraction of natural products: concept and principles. Int J Mol Sci 13(7):8615-8627

Chemat F, Rombaut N, Sicaire A-G, Meullemiestre A, Fabiano-Tixier A-S, Abert-Vian M (2017) Ultrasound assisted extraction of food and natural products. Mechanisms, techniques, combinations, protocols and applications. A review. Ultrason Sonochem 34:540-560

Chemat F, Abert-Vian M, Fabiano-Tixier AS, Strube J, Uhlenbrock L, Gunjevic V, Cravotto GJ (2019) Green extraction of natural products. Origins Curr Status Fut Challenges 118:248-263

Chen X, Fang D, Zhao R, Gao J, Kimatu BM, Hu Q, Chen G, Zhao L (2019) Effects of ultrasound-assisted extraction on antioxidant activity and bidirectional immunomodulatory activity of Flammulina velutipes polysaccharide. Int J Biol Macromol 140:505-514

Ciriminna R, Carnaroglio D, Delisi R, Arvati S, Tamburino A, Pagliaro M (2016) Industrial feasibility of natural products extraction with microwave technology. J ChemistrySelect 1(3):549-555

Cruz PN, Pereira TC, Guindani C, Oliveira DA, Rossi MJ, Ferreira SR (2017) Antioxidant and antibacterial potential of butia (Butia catarinensis) seed extracts obtained by supercritical fluid extraction. J Supercrit Fluids 119:229-237

Cuco RP, Cardozo-Filho L, da Silva C (2019) Simultaneous extraction of seed oil and active compounds from peel of pumpkin (Cucurbita maxima) using pressurized carbon dioxide as solvent. J Supercrit Fluids 143:8-15

De Ancos B, Colina-Coca C, González-Peña D, Sánchez-Moreno C (2015) Bioactive compounds from vegetable and fruit by-products. Biotechnol Bioact Compd Sources Appl. https://doi.org/10.1002/9781118733103.ch1

de Lourdes García-Magaña M, García HS, Bello-Pérez LA, Sáyago-Ayerdi SG, de Oca MM-M (2013) Functional properties and dietary fiber characterization of mango processing by-products (Mangifera indica L., Cv Ataulfo and Tommy Atkins). Plant Foods Hum Nutr 68(3):254-258

Dias JL, Mazzutti S, de Souza JA, Ferreira SR, Soares LA, Stragevitch L, Danielski $L$ (2019) Extraction of umbu (Spondias tuberosa) seed oil using CO2, ultrasound and conventional methods: evaluations of composition profiles and antioxidant activities. J Supercrit Fluids 145:10-18

Ding L, Zhao Q, Zhou X, Tang C, Chen Y, Cai Z (2020) Changes in protein structure and physicochemical properties of egg white by super critical carbon dioxide treatment. J Food Eng 284:110076

Duba KS, Casazza AA, Mohamed HB, Perego P, Fiori L (2015) Extraction of polyphenols from grape skins and defatted grape seeds using subcritical water: experiments and modeling. Food Bioprod Process 94:29-38

Đurđević S, Milovanović S, Šavikin K, Ristić M, Menković N, Pljevljakušić D, Petrović S, Bogdanović A (2017) Improvement of supercritical CO2 and $n$-hexane extraction of wild growing pomegranate seed oil by microwave pretreatment. Ind Crops Prod 104:21-27

Dzah CS, Duan Y, Zhang H, Wen C, Zhang J, Chen G, Ma H (2020) The effects of ultrasound assisted extraction on yield, antioxidant, anticancer and antimicrobial activity of polyphenol extracts: a review. Food Biosci 35:100547

e Santos DN, de Souza LL, Ferreira NJ, de Oliveira AL (2015) Study of supercritical extraction from Brazilian cherry seeds (Eugenia uniflora L.) with bioactive compounds Food Bioprod. Process 94:365-374

El Kantar S, Boussetta N, Lebovka N, Foucart F, Rajha HN, Maroun RG, Louka N, Vorobiev E (2018a) Pulsed electric field treatment of citrus fruits: Improvement of juice and polyphenols extraction. Innov Food Sci Emerg Technol 46:153-161

El Kantar S, Boussetta N, Rajha HN, Maroun RG, Louka N, Vorobiev E (2018b) High voltage electrical discharges combined with enzymatic hydrolysis for extraction of polyphenols and fermentable sugars from orange peels. Food Res Int 107:755-762

Essien SO, Young B, Baroutian S (2020) Recent advances in subcritical water and supercritical carbon dioxide extraction of bioactive compounds from plant materials. Trends Food Sci Technol 97:156-169

Fan Y, Li Z, Liu L, Xi J (2020) Combination of liquid-phase pulsed discharge and ultrasonic for saponins extraction from lychee seeds. Ultrasonics Sonochem 69:105264

Ferrentino G, Giampiccolo S, Morozova K, Haman N, Spilimbergo S, Scampicchio M (2020) Supercritical fluid extraction of oils from apple seeds: Process optimization, chemical characterization and comparison with a conventional solvent extraction. Innov Food Sci Emerg Technol 64:102428

Fidelis M, do Carmo MAV, da Cruz TM, Azevedo L, Myoda T, Furtado MM, Marques MB, Sant'Ana AS, Genovese MI, Oh WY (2020) Camu-camu seed (Myrciaria dubia)-from side stream to an antioxidant, antihyperglycemic, antiproliferative, antimicrobial, antihemolytic, anti-inflammatory, and antihypertensive ingredient. Food Chem 310:125909 
Gallego R, Bueno M, Herrero M (2019) Sub-and supercritical fluid extraction of bioactive compounds from plants, food-by-products, seaweeds and microalgae - an update. Trends Analyt Chem 116:198-213

Garavand F, Rahaee S, Vahedikia N, Jafari SM, Technology (2019) Different techniques for extraction and micro/nanoencapsulation of saffron bioactive ingredients. Trends Food Sci Technol 89:26-44

Gere DR, Randall LG, Callahan D (1997) Supercritical fluid extraction: Principles and applications. In: Techniques and instrumentation in analytical chemistry, Vol. 18, Elsevier, pp. 421-484

Golkar P, Moattar F (2019) Essential oil composition, bioactive compounds, and antioxidant activities in Iberis amara L. Nat Prod Commun. https://doi. org/10.1177/1934578X19846355

Gong P, Wang S, Liu M, Chen F, Yang W, Chang X, Liu N, Zhao Y, Wang J, Chen $X$ (2020) Extraction methods, chemical characterizations and biological activities of mushroom polysaccharides: a mini-review. Carbohydr Res 494:108037

Grassino AN, Ostojić J, Miletić V, Djaković S, Bosiljkov T, Zorić Z, Ježek D, Brnčić SR, Brnčić M (2020) Application of high hydrostatic pressure and ultrasound-assisted extractions as a novel approach for pectin and polyphenols recovery from tomato peel waste. Innov Food Sci Emerg Technol 64:102424

Grzelak-Błaszczyk K, Karlińska E, Grzęda K, Rój E, Kołodziejczyk K (2017) Defatted strawberry seeds as a source of phenolics, dietary fiber and minerals. LWT 84:18-22

Gu L-B, Zhang G-J, Du L, Du J, Qi K, Zhu X-L, Zhang X-Y, Jiang Z-H (2019) Comparative study on the extraction of Xanthoceras sorbifolia Bunge (yellow horn) seed oil using subcritical n-butane, supercritical $\mathrm{CO} 2$, and the Soxhlet method. Lwt 111:548-554

Guil-Guerrero JL, Ramos L, Moreno C, Zúñiga-Paredes J, Carlosama-Yepez M, Ruales P (2016) Plant foods by-products as sources of health-promoting agents for animal production: a review focusing on the tropics. Agron J 108(5):1759-1774

Gullón B, Gagaoua M, Barba FJ, Gullón P, Zhang W, Lorenzo JM (2020) Seaweeds as promising resource of bioactive compounds: Overview of novel extraction strategies and design of tailored meat products. Trends Food Sci Technol 100:1-18

Gustinelli G, Eliasson L, Svelander C, Alminger M, Ahrné L (2018) Supercritical CO2 extraction of bilberry (Vaccinium myrtillus L.) seed oil: Fatty acid composition and antioxidant activity. J Supercrit Fluids 135:91-97

Hamid HSHB, Ismail KSK (2020) Optimization of enzymatic hydrolysis for acid pretreated date seeds into fermentable sugars. Biocatal Agric Biotechnol 24:101530

Ismail BB, Guo M, Pu Y, Wang W, Ye X, Liu D (2019) Valorisation of baobab (Adansonia digitata) seeds by ultrasound assisted extraction of polyphenolics. Optimisation and comparison with conventional methods. Ultrason Sonochem 52:257-267

Ivanović M, Islamčević Razboršek M, Kolar M (2020) Innovative Extraction techniques using deep eutectic solvents and analytical methods for the isolation and characterization of natural bioactive compounds from plant material. Plants 9(11):1428

Jahurul M, Zaidul I, Ghafoor K, Al-Juhaimi FY, Nyam K-L, Norulaini N, Sahena F, Omar AM (2015) Mango (Mangifera indica L.) by-products and their valuable components: a review. Food Chem 183:173-180

Kapoor S, Gandhi N, Tyagi SK, Kaur A, Mahajan B (2020) Extraction and characterization of guava seed oil: a novel industrial byproduct. LWT 132:109882

Koubaa M, Barba FJ, Grimi N, Mhemdi H, Koubaa W, Boussetta N, Vorobiev E (2016) Recovery of colorants from red prickly pear peels and pulps enhanced by pulsed electric field and ultrasound. Innov Food Sci Emerg Technol 37:336-344

Kowalska H, Czajkowska K, Cichowska J, Lenart A (2017) What's new in biopotential of fruit and vegetable by-products applied in the food processing industry. Trends Food Sci Technol 67:150-159

Kulkarni S, Vijayanand P (2010) Effect of extraction conditions on the quality characteristics of pectin from passion fruit peel (Passiflora edulis $\mathrm{f}$. flavicarpa L.). LWT 43(7):1026-1031

Liew SQ, Teoh WH, Tan CK, Yusoff R, Ngoh GC (2018) Subcritical water extraction of low methoxyl pectin from pomelo (Citrus grandis (L.) Osbeck) peels. Int J Biol Macromol 116:128-135
Liu J-j, Gasmalla MAA, Li P, Yang R (2016) Enzyme-assisted extraction processing from oilseeds: principle, processing and application. Innov Food Sci Emerg Technol 35:184-193

Lombardelli C, Liburdi K, Benucci I, Esti M (2020) Tailored and synergistic enzyme-assisted extraction of carotenoid-containing chromoplasts from tomatoes. Food Bioprod Process 121:43-53

Lucci P, Pacetti D, Loizzo MR, Frega NG (2015) Punica granatum cv. Dente di Cavallo seed ethanolic extract: antioxidant and antiproliferative activities. Food Chem 167:475-483

Luengo E, Álvarez I, Raso J (2013) Improving the pressing extraction of polyphenols of orange peel by pulsed electric fields. Innov Food Sci Emerg Technol 17:79-84

Ma J-S, Liu H, Han C-R, Zeng S-J, Xu X-J, Lu D-J, He H-J (2020) Extraction, characterization and antioxidant activity of polysaccharide from Pouteria campechiana seed. Carbohydr Polym 229:115409

Machado I, Faccio R, Pistón M (2019) Characterization of the effects involved in ultrasound-assisted extraction of trace elements from artichoke leaves and soybean seeds. Ultrason Sonochem 59:104752

Mahato N, Sinha M, Sharma K, Koteswararao R, Cho MHJF (2019) Modern extraction and purification techniques for obtaining high purity foodgrade bioactive compounds and value-added co-products from citrus wastes. Foods 8(11):523

Mahindrakar KV, Rathod VK (2020) Ultrasonic assisted aqueous extraction of catechin and gallic acid from Syzygium cumini seed kernel and evaluation of total phenolic, flavonoid contents and antioxidant activity. Chem Eng Process 149:107841

Maran JP, Priya B (2014) Ultrasound-assisted extraction of polysaccharide from Nephelium lappaceum L. fruit peel. Int J Biol Macromol 70:530-536

Maran JP, Sivakumar V, Thirugnanasambandham K, Sridhar R (2014) Microwave assisted extraction of pectin from waste Citrullus lanatus fruit rinds. Carbohydr Polym 101:786-791

Maran JP, Swathi K, Jeevitha P, Jayalakshmi J, Ashvini G (2015) Microwaveassisted extraction of pectic polysaccharide from waste mango peel. Carbohydr Polym 123:67-71

Marić M, Grassino AN, Zhu Z, Barba FJ, Brnčić M, Brnčić SR (2018) An overview of the traditional and innovative approaches for pectin extraction from plant food wastes and by-products: ultrasound-, microwaves-, and enzyme-assisted extraction. Trends Food Sci Technol 76:28-37

Marić B, Pavlić B, Čolović D, Abramović B, Zeković Z, Bodroža-Solarov M, llić $N$, Teslić N (2020) Recovery of high-content $\omega-3$ fatty acid oil from raspberry (Rubus idaeus L.) seeds: chemical composition and functional quality. LWT 130:109627

Martínez-Ramos T, Benedito-Fort J, Watson NJ, Ruiz-López II, Che-Galicia G, Corona-Jiménez E (2020) Effect of solvent composition and its interaction with ultrasonic energy on the ultrasound-assisted extraction of phenolic compounds from Mango peels (Mangifera indica L.). Food Bioprod Process 122:41-54

Medina-Meza IG, Barbosa-Cánovas GV (2015) Assisted extraction of bioactive compounds from plum and grape peels by ultrasonics and pulsed electric fields. J Food Eng 166:268-275

Mehmood A, Ishaq M, Zhao L, Yaqoob S, Safdar B, Nadeem M, Munir M, Wang C (2019) Impact of ultrasound and conventional extraction techniques on bioactive compounds and biological activities of blue butterfly pea flower (Clitoria ternatea L.). Ultrason Sonochem 51:12-19

Memarzadeh SM, Gholami A, Pirbalouti AG, Masoum S (2020) Bakhtiari savory (Satureja bachtiarica Bunge.) essential oil and its chemical profile, antioxidant activities, and leaf micromorphology under green and conventional extraction techniques. Ind Crops Prod 154:112719

Mena-García A, Ruiz-Matute Al, Soria AC, Sanz ML (2019) Green techniques for extraction of bioactive carbohydrates. Trends Analyt Chem 119:115612

Meregalli MM, Puton BMS, Camera FDM, Amaral AU, Zeni J, Cansian RL, Mignoni ML, Backes GT (2020) Conventional and ultrasound-assisted methods for extraction of bioactive compounds from red araçá peel (Psidium cattleianum Sabine). Arab J Chem 13(6):5800-5809

Minh TN, Xuan TD, Tran H-D, Van TM, Andriana Y, Khanh TD, Quan NV, Ahmad A (2019) Isolation and purification of bioactive compounds from the stem bark of Jatropha podagrica. Molecules 24(5):889 
Mushtaq M, Sultana B, Anwar F, Adnan A, Rizvi SS (2015) Enzyme-assisted supercritical fluid extraction of phenolic antioxidants from pomegranate peel. J Supercrit Fluids 104:122-131

Nadar SS, Rao P, Rathod VK (2018) Enzyme assisted extraction of biomolecules as an approach to novel extraction technology: a review. Int Food Res J 108:309-330

Narváez-Cuenca C-E, Inampues-Charfuelan M-L, Hurtado-Benavides A-M, Parada-Alfonso F, Vincken J-P (2020) The phenolic compounds, tocopherols, and phytosterols in the edible oil of guava (Psidium guava) seeds obtained by supercritical CO2 extraction. J Food Compos Anal 89:103467

Natolino A, Da Porto C (2019) Supercritical carbon dioxide extraction of pomegranate (Punica granatum L.) seed oil: Kinetic modelling and solubility evaluation. Innov Food Sci Emerg Technol 151:30-39

Ojha KS, Aznar R, O'Donnell C, Tiwari BK (2020) Ultrasound technology for the extraction of biologically active molecules from plant, animal and marine sources. Trends Analyt Chem 122:115663

Okolie CL, Akanbi TO, Mason B, Udenigwe CC, Aryee AN (2019) Influence of conventional and recent extraction technologies on physicochemical properties of bioactive macromolecules from natural sources: a review. Int Food Res J 116:827-839

Padayachee A, Day L, Howell K, Gidley M (2017) Complexity and health functionality of plant cell wall fibers from fruits and vegetables. Crit Rev Food Sci Nutr 57(1):59-81

Panja P (2018) Green extraction methods of food polyphenols from vegetable materials. Curr Opin Food Sci 23:173-182

Parashar S, Sharma H, Garg M (2014) Antimicrobial and antioxidant activities of fruits and vegetable peels: a review. J Pharmacogn Phytochem. 3(1):160-164

Parniakov O, Roselló-Soto E, Barba FJ, Grimi N, Lebovka N, Vorobiev E (2015) New approaches for the effective valorization of papaya seeds: Extraction of proteins, phenolic compounds, carbohydrates, and isothiocyanates assisted by pulsed electric energy. Int Food Res J 77:711-717

Parniakov O, Barba FJ, Grimi N, Lebovka N, Vorobiev E (2016) Extraction assisted by pulsed electric energy as a potential tool for green and sustainable recovery of nutritionally valuable compounds from mango peels. Food Chem 192:842-848

Pereira MG, Hamerski F, Andrade EF, Scheer AdP, Corazza ML (2017) Assessment of subcritical propane, ultrasound-assisted and Soxhlet extraction of oil from sweet passion fruit (Passiflora alata Curtis) seeds. J Supercrit Fluids 128:338-348

Peso-Echarri P, González-Bermúdez CA, Ros-Berruezo G, Martínez-Graciá C, Frontela-Saseta C (2015) Polysaccharides as bioactive components of functional food. J Funct Polym. https://doi.org/10.1002/9781119108 580.ch7

Pinto D, de la Luz Cádiz-Gurrea M, Sut S, Ferreira AS, Leyva-Jimenez FJ, Dall'Acqua S, Segura-Carretero A, Delerue-Matos C, Rodrigues F (2020) Valorisation of underexploited Castanea sativa shells bioactive compounds recovered by supercritical fluid extraction with $\mathrm{CO} 2$ : A response surface methodology approach. J. CO2 Util. 40:101194.

Plazzotta S, Ibarz R, Manzocco L, Martín-Belloso O (2021) Modelling the recovery of biocompounds from peach waste assisted by pulsed electric fields or thermal treatment. J Food Eng 290:110196

Pourmortazavi SM, Hajimirsadeghi SS (2007) Supercritical fluid extraction in plant essential and volatile oil analysis. J Chromatogr A 1163(1-2):2-24

Puértolas E, Cregenzán O, Luengo E, Álvarez I, Raso J (2013) Pulsed-electricfield-assisted extraction of anthocyanins from purple-fleshed potato. Food Chem 136(3-4):1330-1336

Raihana AN, Marikkar J, Amin I, Shuhaimi M (2015) A review on food values of selected tropical fruits' seeds. Int J Food Prop 18(11):2380-2392

Raj GB, Dash KK (2020) Ultrasound-assisted extraction of phytocompounds from dragon fruit peel: optimization, kinetics and thermodynamic studies. Ultrason Sonochem 68:105180

Raje V, Lokhande S, More SS, IJoRiE, Science, Management (2019) Techniques for extraction and isolation of natural products: a comprehensive review. Int J Res Eng Sci Manage 2(10):226-230

Redondo D, Arias E, Oria R, Venturini ME (2017) Thinned stone fruits are a source of polyphenols and antioxidant compounds. J Sci Food Agr 97(3):902-910

Roberts J, Caserio M (1977) Separation and purification. Identification of organic compounds by spectroscopic techniques. Chapter 9:257-349.
Roda A, De Faveri DM, Giacosa S, Dordoni R, Lambri M (2016) Effect of pretreatments on the saccharification of pineapple waste as a potential source for vinegar production. J Clean Prod 112:4477-4484

Rodrigues LGG, Mazzutti S, Vitali L, Micke GA, Ferreira SRS (2019) Recovery of bioactive phenolic compounds from papaya seeds agroindustrial residue using subcritical water extraction. Biocatal Agric Biotechnol 22:101367

Rodsamran P, Sothornvit R (2019a) Extraction of phenolic compounds from lime peel waste using ultrasonic-assisted and microwave-assisted extractions. Food Biosci 28:66-73

Rodsamran P, Sothornvit R (2019b) Preparation and characterization of pectin fraction from pineapple peel as a natural plasticizer and material for biopolymer film. Food Bioprod Process 118:198-206

Saifullah M, McCullum R, McCluskey A, Vuong Q (2020) Comparison of conventional extraction technique with ultrasound assisted extraction on recovery of phenolic compounds from lemon scented tea tree (Leptospermum petersonii) leaves. Heliyon 6(4):e03666

Saleem M, Saeed MT (2020) Potential application of waste fruit peels (orange, yellow lemon and banana) as wide range natural antimicrobial agent. J King Saud Univ Sci 32(1):805-810

Salgın U, Salgın S, Ekici DD, Uludal: G (2016) Oil recovery in rosehip seeds from food plant waste products using supercritical $\mathrm{CO} 2$ extraction. J Supercrit Fluids 118:194-202

Sanchez-Maldonado AF (2014) Mode of action, interaction and recovery of plant secondary metabolites for potential applications as food preservatives.

Sasidharan S, Chen Y, Saravanan D, Sundram K, Latha LY, Medicines A (2011) Extraction, isolation and characterization of bioactive compounds from plants' extracts. Afr J Tradit Complem. https://doi.org/10.4314/ajtcam. v8i1.60483

Shorstkii I, Khudyakov D, Mirshekarloo MS (2020) Pulsed electric field assisted sunflower oil pilot production: Impact on oil yield, extraction kinetics and chemical parameters. Innov Food Sci Emerg Technol 60:102309

Singh B, Singh JP, Kaur A, Singh N (2017) Phenolic composition and antioxidant potential of grain legume seeds: a review. Int Food Res J 101:1-16

Smith RM (2003) Before the injection-modern methods of sample preparation for separation techniques. J Chromatogr A 1000(1-2):3-27

Sood A, Gupta M (2015) Extraction process optimization for bioactive compounds in pomegranate peel. Food Biosci 12:100-106

Talekar S, Patti AF, Singh R, Vijayraghavan R, Arora A (2018) From waste to wealth: high recovery of nutraceuticals from pomegranate seed waste using a green extraction process. Ind Crops Prod 112:790-802

Tanaka M, Takamizu A, Hoshino M, Sasaki M, Goto M (2012) Extraction of dietary fiber from Citrus junos peel with subcritical water. Food Bioprod Process 90(2):180-186

Taofiq O, Corrêa RC, Barros L, Prieto M, Bracht A, Peralta RM, González-Paramás AM, Barreiro MF, Ferreira IC (2019) A comparative study between conventional and non-conventional extraction techniques for the recovery of ergosterol from Agaricus blazei Murrill. Int Food Res J 125:108541

Thirugnanasambandham K, Sivakumar V, Maran JP (2014) Process optimization and analysis of microwave assisted extraction of pectin from dragon fruit peel. Carbohydr Polym 112:622-626

Tongkham N, Juntasalay B, Lasunon P, Sengkhamparn N (2017) Dragon fruit peel pectin: microwave-assisted extraction and fuzzy assessment. Agric Nat Resour 51(4):262-267

Torres-León C, Rojas R, Serna-Cock L, Belmares-Cerda R, Aguilar CN (2017) Extraction of antioxidants from mango seed kernel: Optimization assisted by microwave. Food Bioprod Process 105:188-196

Torres-Ossandón MJ, Vega-Gálvez A, López J, Stucken K, Romero J, Di Scala K (2018) Effects of high hydrostatic pressure processing and supercritical fluid extraction on bioactive compounds and antioxidant capacity of Cape gooseberry pulp (Physalis peruviana L.). J Supercrit Fluids $138: 215-220$

Trigo JP, Alexandre EM, Saraiva JA, Pintado ME (2020) High value-added compounds from fruit and vegetable by-products-characterization, bioactivities, and application in the development of novel food products. Crit Rev Food Sci Nutr 60(8):1388-1416

Upadhyay R, Ramalakshmi K, Rao LJM (2012) Microwave-assisted extraction of chlorogenic acids from green coffee beans. Food Chem 130(1):184-188 
Vardanega R, Nogueira GC, Nascimento CD, Faria-Machado AF, Meireles MAA (2019) Selective extraction of bioactive compounds from annatto seeds by sequential supercritical CO2 process. J Supercrit Fluids 150:122-127

Vasco-Correa J, Zapata ADZ (2017) Enzymatic extraction of pectin from passion fruit peel (Passiflora edulis f. flavicarpa) at laboratory and bench scale. LWT 80:280-285

Vij T, Prashar Y (2015) A review on medicinal properties of Carica papaya Linn. Asian Pac J Trop Dis 5(1):1-6

Walia M, Rawat K, Bhushan S, Padwad YS, Singh B (2014) Fatty acid composition, physicochemical properties, antioxidant and cytotoxic activity of apple seed oil obtained from apple pomace. J Sci Food Agr 94(5):929-934

Wang K, Xie X, Zhang Y, Huang Y, Zhou S, Zhang W, Lin Y, Fan H (2018) Combination of microwave-assisted extraction and ultrasonic-assisted dispersive liquid-liquid microextraction for separation and enrichment of pyrethroids residues in Litchi fruit prior to HPLC determination. Food Chem 240:1233-1242

Wang L, Boussetta N, Lebovka N, Vorobiev E (2020) Cell disintegration of apple peels induced by pulsed electric field and efficiency of bio-compound extraction. Food Bioprod Process 122:13-21

Wu Z, Li H, Wang Y, Yang D, Tan H, Zhan Y, Yang Y, Luo Y, Chen G (2019) Optimization extraction, structural features and antitumor activity of polysaccharides from Z. jujuba cv. Ruoqiangzao Seeds Int J Biol Macromo 135:1151-1161

Xu C, Yagiz Y, Borejsza-Wysocki W, Lu J, Gu L, Ramírez-Rodrigues MM, Marshall MR (2014) Enzyme release of phenolics from muscadine grape (Vitis rotundifolia Michx.) skins and seeds. Food Chem 157:20-29

Yalcin H, Çapar TD (2017) Bioactive compounds of fruits and vegetables. In: Minimally processed refrigerated fruits and vegetables, Springer, $\mathrm{pp}$ 723-745

Zengin G, Cvetanović A, Gašić U, Tešić Ž, Stupar A, Bulut G, Sinan KI, Uysal S, Picot-Allain MCN, Mahomoodally MF (2020) A comparative exploration of the phytochemical profiles and bio-pharmaceutical potential of Helichrysum stoechas subsp. barrelieri extracts obtained via five extraction techniques. Process Biochem 91:113-125

Zhang Q-W, Lin L-G, Ye W-C (2018) Techniques for extraction and isolation of natural products: a comprehensive review. Chin Med 13(1):1-26

Zhang R, Li S, Zhu Z, He J (2019) Recent advances in valorization of Chaenomeles fruit: a review of botanical profile, phytochemistry, advanced extraction technologies and bioactivities. rends. Food Sci Technol 91:467-482

Zhang J, Wen C, Zhang H, Duan Y, Ma H (2020) Recent advances in the extraction of bioactive compounds with subcritical water: a review. Trends Food Sci Technol 95:183-195

Zuin VG, Ramin LZ (2018) Green and sustainable separation of natural products from agro-industrial waste: challenges, potentialities, and perspectives on emerging approaches. Chemistry and Chemical Technologies in Waste Valorization, pp 229-282

Zwingelstein M, Draye M, Besombes J-L, Piot C, Chatel G (2020) Viticultural wood waste as a source of polyphenols of interest: opportunities and perspectives through conventional and emerging extraction methods. J Waste Manag 102:782-794

\section{Publisher's Note}

Springer Nature remains neutral with regard to jurisdictional claims in published maps and institutional affiliations.

\section{Submit your manuscript to a SpringerOpen ${ }^{\circ}$ journal and benefit from:}

- Convenient online submission

- Rigorous peer review

- Open access: articles freely available online

- High visibility within the field

- Retaining the copyright to your article

Submit your next manuscript at $\boldsymbol{\nabla}$ springeropen.com 